\title{
CODZIENNOŚĆ W SUDECKICH SANATORIACH W LATACH 1950-1966
}

Zarys treści: Po 1945 r. uzdrowiska przekształcono całkowicie, zarówno pod względem systemu leczenia, działalności kuracyjnej, jak i sposobu ich administrowania. Upaństwowione kurorty stały się nieodłączną częścią socjalistycznej służby zdrowia oraz centralnie sterowanej gospodarki. W artykule skoncentrowano się przede wszystkim na aspektach społeczno-kulturowych, podejmując m.in. watki charakteru uzdrowisk czy oferty przygotowanej dla kuracjuszy. Celem publikacji jest pokazanie, jak w okresie powojennym na nowo kształtowało się życie uzdrowiskowe i jakie trudności temu towarzyszyły. Przedstawiono specyfikę pobytu dorosłych kuracjuszy w ramach lecznictwa zamkniętego, podczas którego chory stale przebywał w sanatorium.

The content outline: After 1945, health resorts were totally transformed, both as regards the treatment and therapeutical systems, and their administration. Health resorts, taken over by the state, became an integral part of the socialist national health service and a centrally managed economy. The article focuses mainly on socio-cultural aspects, taking up such questions as the character of health resorts or their proposal for patients. The purpose of the study is to demonstrate how the offer of health and rehabilitation resorts was reshaped in the post-war reality and what difficulties had to be overcome. A specificity of the inpatient care is presented when adult patients are housed in a sanatorium.

Słowa kluczowe: uzdrowiska dolnośląskie po 1945 r., PRL, socjalistyczna służba zdrowia, życie codzienne

Keywords: Lower Silesia health resorts after 1945, Polish People's Republic, socialist health service, everyday life 


\section{Wprowadzenie}

W dotychczasowych polskich badaniach omijano zagadnienia odnoszące się do historii uzdrowisk po 1945 r. Dotyczy to również dolnoślaskich i sudeckich miejscowości kuracyjnych. Zakres terytorialny artykułu obejmuje polska, po 1945 r., część masywu Sudetów oraz Przedgórze Sudeckie ${ }^{1}$. Analizą zostały objęte uzdrowiska, które w latach 1950-1966 prowadziły działalność lecznicza pod auspicjami Państwowego Przedsiębiorstwa „Polskie Uzdrowiska” i Centralnego Zarządu Uzdrowisk, tworząc jednocześnie Państwowe Przedsiębiorstwa Uzdrowiskowe. Cezura początkowa jest rok 1950, kiedy w pełni przekształcono i sformalizowano lecznictwo uzdrowiskowe. Wraz ze zmianami na poziomie struktur administracyjnych reformowano cały system leczniczy. Dopiero od tego momentu można mówić o całkowitym „uspołecznieniu" tego działu służby zdrowia. Końcowa cezura jest zaś uchwalenie w 1966 r. ustawy o uzdrowiskach i lecznictwie uzdrowiskowym. Wydanie tego aktu prawnego kończy przemiany w powojennym lecznictwie uzdrowiskowym.

W opracowaniach dotyczących dziejów Dolnego Śląska po 1945 r. temat uzdrowisk nie jest właściwie podejmowany. Do tej pory nie ukazała się żadna publikacja kompleksowo traktująca o sytuacji śląskich kurortów po II wojnie światowej. Dostępne piśmiennictwo jest nader skape i ma różną wartość poznawcza. Również kwestia życia codziennego nie była poddana głębszym analizom ${ }^{2}$. Podstawą ustaleń zawartych $\mathrm{w}$ artykule sa materiały archiwalne zgromadzone w Archiwum Akt Nowych w Warszawie, Archiwum Państwowym we Wrocławiu oraz w jego oddziale w Kamieńcu Ząbkowickim. Jako uzupełnienie służy zaś

${ }^{1}$ Przedgórze Sudeckie rozumiane jako obszar położony na północny wschód od Sudetów, tworzony przez Wzgórza Strzegomskie, Wzgórza Niemczańsko-Strzelińskie; Stownik geograficzno-krajoznawczy Polski, red. M.I. Mileska, Warszawa 2000, s. 790.

${ }^{2}$ Lukę badawczą uzupełnia moja niepublikowana rozprawa doktorska przygotowana pod kierunkiem prof. J. Kęsika w Instytucie Historycznym Uniwersytetu Wrocławskiego: K. Janusiak, Uzdrowiska w polskich Sudetach i Przedgórzu Sudeckim (organizacja, infrastruktura, działalność lecznicza), Wrocław 2016, na bazie której powstał niniejszy artykuł. W'śród wydanych opracowań wyjątek stanowi pozycja: R.M. Łuczyński, Uzdrowiska sudeckie w latach 1945-1950, Wrocław 2015. Autor w skrócie opisuje m.in. organizacje uzdrowiskowe, lecznictwo, frekwencję. Fragmenty pracy zostały poświęcone również życiu kulturalnemu i rozrywkom. Nie dokonano jednak szerszej analizy wymienionych zjawisk i nie przedstawiano ich w kontekście powojennych zmian, które dotknęły lecznictwo uzdrowiskowe w całym regionie. Godna uwagi pozycja jest też: Uzdrowiska dolnoślaskie i ich okolice. Balneologia, historia, przyroda, sztuka, red. A. Falkiewicz, M. Starzewska, Wrocław 1975. 
specjalistyczna prasa, wydawana m.in. przez Uzdrowiska Polskie czy Instytut Balneologiczny.

W artykule skupiłam się przede wszystkim na aspektach społeczno-kulturowych, podejmując m.in. wątki charakteru uzdrowisk, oferty przygotowanej dla kuracjuszy. Celem publikacji jest pokazanie, jak w okresie powojennym na nowo kształtowało się życie uzdrowiskowe i jakie trudności temu towarzyszyły. Przyglądając się codzienności w sudeckich sanatoriach, chciałam odpowiedzieć na pytania: jaki wpływ na funkcjonowanie ośrodków miała centralnie sterowana gospodarka, niedobory oraz przemiany w służbie zdrowia. W artykule została przedstawiona specyfika pobytu dorosłych kuracjuszy w ramach lecznictwa zamkniętego - sanatoryjnego, podczas którego chory stale przebywał $\mathrm{w}$ sanatorium. Tym samym nie poruszono tu zagadnień związanych z leczeniem ambulatoryjnym - otwartym oraz z lecznictwem dziecięcym.

\section{„Po zdrowie i radość życia do Uzdrowisk Dolnośląskich”3}

W 1945 r., na skutek przesunięcia polskich granic na zachód, znaczna część krajowych uzdrowisk znajdowała się na terenie Sudetów. Bogactwa naturalne eksploatowane w miejscowych kurortach oraz ich infrastruktura miały wpływ na kształtowanie się całego powojennego lecznictwa uzdrowiskowego. Jego przekształcenia, ściśle związane ze zmianami w całej służbie zdrowia, rozpoczęły się od 1948 r. Stopniowo likwidowano wielosektorowy system opieki leczniczej. Ujednolicono go i centralizowano. Rozwiązania przejęte $\mathrm{z}$ okresu międzywojennego należało dostosować do obowiązujących warunków politycznych i gospodarczych, przede wszystkim centralnie planowej gospodarki. Ministerstwo Zdrowia dążyło do stworzenia jednolitej i powszechnej opieki zdrowotnej, która byłaby dostępna dla wszystkich grup społecznych obywateli ${ }^{4}$. Skutkiem przemian $\mathrm{w}$ powojennej służbie zdrowia było przejęcie przez państwo całkowitej kontroli nad lecznictwem. Scentralizowany system obją wszystkie aspekty opieki zdrowotnej. Kluczowe zmiany nastapiły na przełomie lat 40. i 50., kiedy uzdrowiska zostały w pełni przestawione

${ }^{3}$ Państwowe Uzdrowiska Dolnoślaskie. Informator na sezon wiosenny 1946, b.m. i d.w., s. 22.

${ }^{4}$ P. Grata, Od Drugiej Rzeczypospolitej do Polski Ludowej. Ewolucja systemu ochrony zdrowia $w$ Polsce $w$ latach 1944-1950, „Polska 1944/45-1989. Studia i Materiały" 15,2017 , s. $6,13-14$. 
na tzw. lecznictwo społeczne ${ }^{5}$. Wprowadzono system skierowań na bezpłatna kurację oraz wyodrębniono lecznictwo otwarte - ambulatoryjne i zamknięte - sanatoryjne. W całym kraju przyjęto taki sam system kwalifikacji chorych, ograniczając przy tym liczbę pacjentów prywatnych $^{6}$. Jednocześnie należy podkreślić, że w pierwszych powojennych sezonach dominowały, podobnie jak przed 1945 r., wyjazdy komercyjne, indywidualne. Od 1948 r., wraz z przemianami organizacyjnymi w całej służbie zdrowia, zaczęto tworzyć podwaliny dla masowego, zorganizowanego uzdrowiskowego lecznictwa społecznego.

$\mathrm{Na}$ początku lat 50. został opracowany specjalny system opisujący jak, przynajmniej w teorii, powinien wyglądać pobyt chorego w uzdrowisku. Dzięki niemu kuracjusz miał czuć się komfortowo już od momentu przyjazdu na dworzec. „Jedna z form uspołecznionej obsługi kuracjusza i opieki nad nim w uzdrowiskach powinno stanowić zainteresowanie się Zarządów Państwowych Uzdrowisk istniejącymi warunkami dojazdu kuracjuszy od dworców, po przyjeździe do miejscowości uzdrowiskowych, do biur usługowych Zarządów Państwowych Uzdrowisk" stwierdzali w piśmie z 1950 r. przedstawiciele Naczelnej Dyrekcji ${ }^{7}$. Po otrzymaniu skierowania i przybyciu do uzdrowiska dalsze kroki kuracjusza uzależnione były od tego, czy miał leczyć się ambulatoryjne, czy sanatoryjne. W pierwszym przypadku musiał udać się do odpowiedniego domu wczasowego, w drugim do biura usług. ${ }^{8}$. Te ostatnie zorganizowano pod koniec lat 40. Ich celem było usprawnienie i ułatwienie procedury przyjęcia do sanatorium. W założeniu miały działać tak, „aby kuracjusz po przybyciu do uzdrowiska pozbawiony był wszelkich kłopotów związanych z pobytem i leczeniem".

$\mathrm{W}$ teorii pierwsze chwile po opuszczeniu pociagu na dworcu docelowym miały wyglądać następująco: „Na stacji czeka na nas biało-czerwony autokar. Chwila jazdy i zatrzymuje się przed jasnym gmachem

5 AAN, Naczelna Dyrekcja „Polskie Uzdrowiska” (dalej: ND „PU”), sygn. 4/3, Odpis protokołu z 23 IV 1951 r. ze zdania Państwowego Uzdrowiska Kudowa nowo mianowanemu dyrektorowi T. Janowskiemu.

${ }^{6}$ Podział na lecznictwo otwarte i zamknięte wprowadzono w 1950 r. Ostatecznie ukształtował się w 1951 r.; AAN, ND „PU”, sygn. 5/23, Zagadnienia lecznictwa uzdrowiskowego w 1950 r.; J. Dobrzyński, Uzdrowiska państwowe w roku 1951 (szkic sprawozdawczo-statystyczny), „Balneologia Polska” 4, 1953, s. 119.

7 AAN, ND „PU”, sygn. 1/2, Pismo okólne nr 14 ND „PU” w sprawie przejazdów kuracjuszy między dworcami a uzdrowiskami, 6 V $1950 \mathrm{r}$.

8 S. Cegliński, M. Kalinowski, Jak leczyć się $w$ uzdrowisku (Poradnik dla skierowanych na leczenie uzdrowiskowe), Warszawa 1957, s. 13.

${ }_{9} Z$ obrad Ministerstwa Zdrowia. Lecznictwo uzdrowiskowe w Polsce Ludowej, „Służba Zdrowia” 1949, nr 3, s. 2. 
Biura Obsługi. Tam po załatwieniu formalności wszyscy otrzymują skierowania do odpowiedniego pawilonu"10. Jednak nie zawsze na kuracjuszy czekał autobus lub pracownicy. Często na dworcu nie było specjalnych komunikatów. Ograniczano się jedynie do tablicy informacyjnej i drogowskazów na trasie do uzdrowiska ${ }^{11}$. Zdarzało się, że nie było nawet i tego typu udogodnień. Za przykład może posłużyć Szczawno-Zdrój, gdzie od przystanku tramwajowego do budynku biura usług nie zamieszczono żadnych wskazówek dla kuracjuszy, oraz Świeradów-Zdrój, gdzie ani na dworcu autobusowym, ani kolejowym nie było tablic informacyjnych ${ }^{12}$. W Dusznikach-Zdroju autobus przyjeżdżał po pacjentów jedynie w niektóre dni. W pozostałe musieli oni radzić sobie sami ${ }^{13}$. Podobnie było w Polanicy-Zdroju oraz Kudowie-Zdroju. W tej drugiej miejscowości niedogodności potęgowała odległość między dworcem a biurem usług oraz fakt, że do transportu kuracjuszy uzdrowisko dysponowało jedynie ciężarówką (!) wyposażoną w nieumocowane ławki i plandekę. W przypadkach, kiedy ten dość osobliwy środek transportu nie przyjeżdżał, pacjentom pozostawało wynajęcie dorożki lub piesza wędrówka z bagażami ${ }^{14}$. Do pozytywnych wzorców należy zaliczyć Cieplice-Zdrój i Lądek-Zdrój. W pierwszej miejscowości na przystanku tramwajowym na kuracjuszy czekał pracownik uzdrowiska, który zabierał ich do punktu przyjęć ${ }^{15}$. W drugim przypadku procedura odebrania kuracjuszy odbywała się według zaleceń: „w dniach między 1 a 8 każdego turnusu do pociagów dalekobieżnych wyjeżdża autobus Z[arządu] P[aństwowego] U[zdrowiska] z informatorem, który zabiera przybyłych kuracjuszy i wczasowiczów. W późniejszych okresach tzn. po 8 przyjeżdżający kuracjusze, względnie wczasowicze, informowani sa przez zainstalowane na dworcu

${ }^{10}$ Z. Okuniewski, Wczasy lecznicze w Polanicy dla świata pracy, „Służba Zdrowia” 1952, nr 27, s. 4.

${ }_{11}$ Tak było np. w Dusznikach-Zdroju; AAN, ND „PU”, sygn. 4/1, Protokół kontroli lotnej w Zarządzie Państwowego Uzdrowiska [dalej: ZPU] Duszniki-Zdrój, 31 VII $1950 \mathrm{r}$.

12 AAN, ND „PU”, sygn. 4/2, Sprawozdanie z kontroli lotnej w ZPU Szczawno-Zdrój, 27-28 VIII 1950 r.; tamże, Sprawozdanie z kontroli lotnej w ZPU Świeradów-Zdrój, 29 VIII 1950 r.; AAN, ND „PU”, sygn. 4/6, Protokół lustracji doraźnej w ZPU Świeradów-Zdrój, 31 V-1 VI 1951 r.

${ }_{13}$ Tamże, sygn. 4/3, Protokół lustracji doraźnej w ZPU Duszniki-Zdrój, 18-21 V $1951 \mathrm{r}$.

14 Tamże, sygn. 4/4, Protokół lustracji doraźnej w ZPU Kudowa-Zdrój, 21-22 V 1951 r.; tamże, sygn. 4/5, Protokół lustracji doraźnej w ZPU Polanica-Zdrój, 15-17 V $1951 \mathrm{r}$.

15 Tamże, sygn. 4/3, Protokół kontroli doraźnej w ZPU Cieplice-Zdrój, 29-30 V $1951 \mathrm{r}$. 
głośniki”16. Należy podkreślić, że taki przejazd był płatny. To samo dotyczyło drogi powrotnej ${ }^{17}$. Procedura przyjęcia kuracjuszy do uzdrowiska była także dobrze zorganizowana w Długopolu-Zdroju. Mógł na to wpływać fakt, że było to niewielkie uzdrowisko - budynek dworca i biura usług dzieliła niewielka odległość, również sanatoria położone były blisko siebie, co z pewnością ułatwiało odpowiednie zajęcie się pacjentami ${ }^{18}$.

Po przybyciu do zakładu leczniczego kuracjusze musieli być poddawani kontrolom sanitarnym, np. pod kątem wszawicy, oraz kapielom higienicznym ${ }^{19}$. Wizyta lekarska wyznaczana była przez pielęgniarkę ${ }^{20}$. Teoretycznie chorzy mieli być badani przez lekarza wkrótce po przybyciu do sanatorium. Nie zawsze jednak tak było. Zdarzały się przypadki, że ordynowano zabiegi bez jakiekolwiek badania ${ }^{21}$. Wpływała na to m.in. zła organizacja dyżurów i brak kadry lekarskiej.

Pokoje w sanatoriach były wieloosobowe, zwykle dwu-czteroosobowe, choć zdarzały się i siedmio- czy ośmioosobowe (!). W większości zainstalowane były umywalki z ciepła i zimna woda ${ }^{22}$. Zgodnie z założeniami mieli być w nich razem kwaterowani pracownicy fizyczni, chłopi, inteligencja. „Dawniej obowiązujące przepisy towarzyskie częściowo należa już do przeszłości. Dziś odrzuciliśmy konwenanse, zachowujemy się naturalnie, niemniej jednak powinnyśmy pamiętać o pewnych zwyczajach, które nam i otoczeniu ułatwią i uprzyjemnią współżycie” - radzono w poradniku dla skierowanych na leczenie uzdrowiskowe ${ }^{23}$. Przydział pokoju miał być uzależniony również od stanu zdrowia. Kuracjusze ciężej

16 Tamże, sygn. 4/4, Sprawozdanie z lustracji doraźnej w ZPU Lądek-Zdrój, 23 V 1951 r.; AAN, Centralny Zarząd Uzdrowisk (dalej: CZU), sygn. 2/24, Sprawozdanie z podróży służbowej do Lądka-Zdroju, 10-14 I $1956 \mathrm{r}$.

17 AAN, ND „PU”, sygn. 4/7, Pismo do Ministerstwa Zdrowia, Biura Skarg i zażaleń, skierowane przez jedną z kuracjuszek uzdrowiska w Lądku-Zdroju, 1952 r.

18 Tamże, sygn. 4/3, Sprawozdanie z lustracji doraźnej w ZPU Długopole-Zdrój, $24 \mathrm{~V} 1951 \mathrm{r}$.

19 Tamże, sygn. 4/4, Sprawozdanie z lustracji doraźnej w ZPU Lądek-Zdrój, 23 V $1951 \mathrm{r}$.

20 S. Cegliński, M. Kalinowski, dz. cyt., s. 14.

${ }^{21}$ AAN, ND „PU”, sygn. 4/2, Sprawozdanie z kontroli lotnej w ZPU Świeradów-Zdrój, 29 VIII 1950 r.

${ }^{22}$ O standardzie wyposażenia pokoi zob. m.in.: tamże, sygn. 4/1, Protokół kontroli w ZPU Duszniki-Zdrój, 19 V-7 VI 1950 r.; Archiwum Państwowe we Wrocławiu, Oddział w Kamieńcu Ząbkowickim (dalej: APKZ), Uzdrowisko Lądek-Długopole, sygn. 180, Karta ewidencyjna pawilonu sanatoryjnego Uzdrowisko Kudowa w Kudowie-Zdroju, sygn. 5/32, Plan obłożenia sanatorium na 1955 r.

${ }^{23}$ S. Cegliński, M. Kalinowski, dz. cyt., s. 14. 


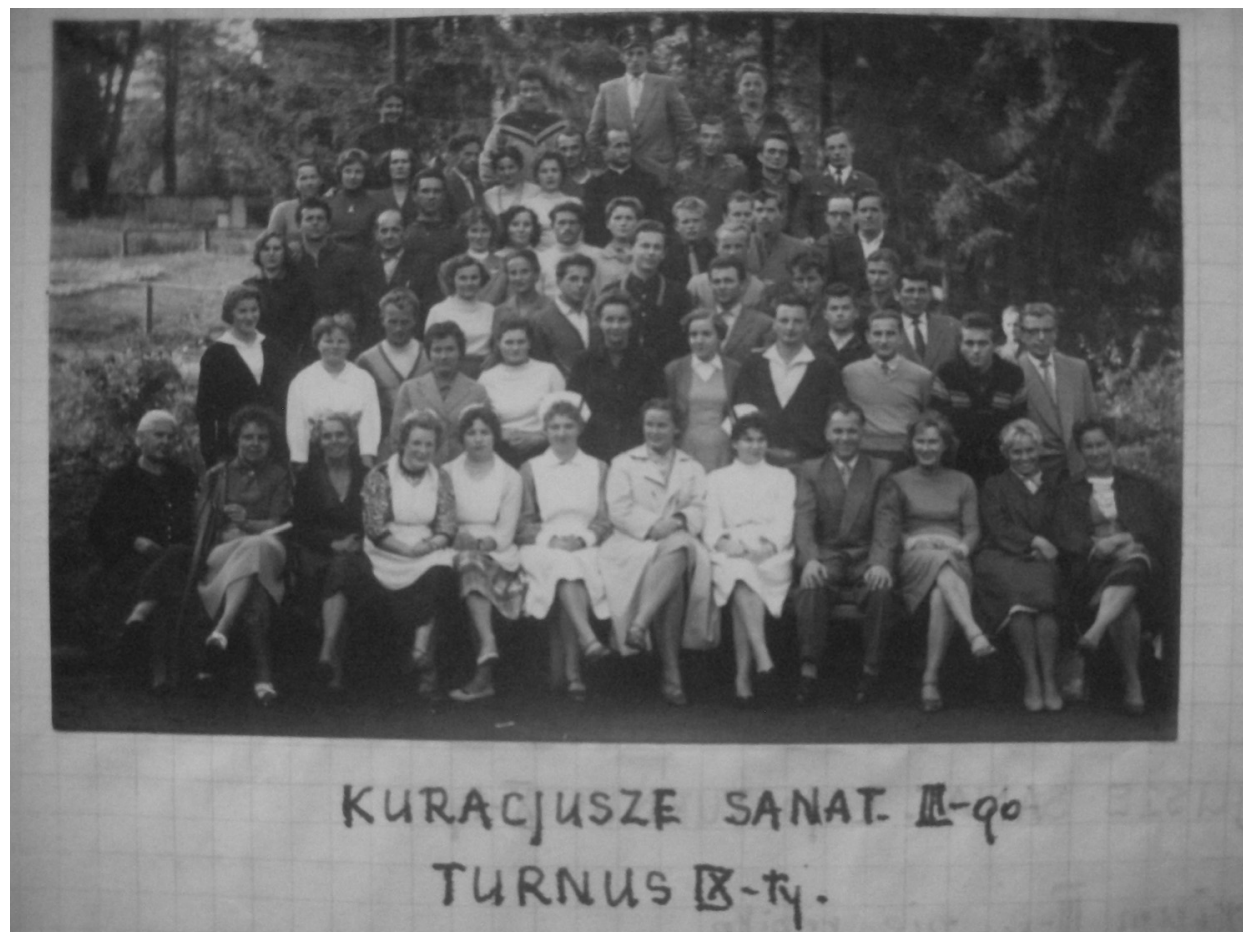

Il. 1. Fragment kroniki kuracjuszy z Długopola-Zdroju, 1960 r.; APKZ, Uzdrowisko Długopole w Długopolu-Zdroju, sygn. 16, Kronika turnusów kuracjuszy Uzdrowiska Długopole, $1960 \mathrm{r}$.

chorzy powinni być kwaterowani na parterze, w sanatoriach, gdzie znajdowały się pomieszczenia zabiegowe. Tych zasad nie zawsze przestrzegano $^{24}$.

Jakie warunki panowały w sanatoriach? Propagandowy obraz kreślony w poradnikach czy artykułach znacznie różnił się od tego, jaki wyłania się z lektury protokołów pokontrolnych. Ze sprawozdań wynika, że bardzo często pokoje nie były należycie przygotowane do przyjęcia kuracjuszy, np. w Cieplicach-Zdroju „w pawilonie VII »Polonia« na parterze i I piętrze [...] pokoje były niesprzątnięte. Nowych kuracjuszy wprowadzono do nieuporządkowanego i nieopalonego pokoju - kuracjusze niezadowoleni - przyjechali z drogi zziębnięci”"25. Do ważniejszych uchybień należy dodać również brak bieżącej ciepłej wody, który dotykał m.in.

${ }^{24}$ AAN, ND „PU”, sygn. 4/4, Protokół lustracji doraźnej w ZPU Kudowa-Zdrój, 21-22 V $1951 \mathrm{r}$.

25 Tamże, sygn. 4/3, Protokół kontroli Dyrekcji Państwowego Uzdrowiska [dalej: DPU] Cieplice-Zdrój, 30 XI-9 XII 1951 r. 
pacjentów przebywajacych w sanatorium „Orzeł” w Szczawnie-Zdroju ${ }^{26}$. Podobnie było w Długopolu-Zdroju, gdzie na skutek zbyt niskiego ciśnienia woda nie docierała na wyższe piętra budynków sanatoryjnych ${ }^{27}$.

Standard pomieszczeń był bolączką wielu uzdrowisk. Nie wszystkie sanatoria nadawały się do przyjęcia chorych. Taki problem występował m.in. w Dusznikach-Zdroju. Kiedy obłożenie w sanatoriach wzrastało, kuracjuszy kwaterowano w budynku „Lenino”, w którym nie było ani bieżącej wody, ani ogrzewania ${ }^{28}$. Problem narastał w szczególności podczas trwania Festiwalu Chopinowskiego. Uzdrowisko miało w tym czasie duże kłopoty organizacyjne. Część pomieszczeń zarezerwowana była dla gości festiwalowych. Pomimo to instytucje kierujące wysyłały do uzdrowiska nadmierną liczbę kuracjuszy. Dla chorych nie było miejsca w sanatoriach. W jednym z protokołów kontroli odnotowano: „w okresie Festiwalu kuracjusze pomieszczeni w sanatorium "Lenino« według ich oświadczeń, byli zaniedbywani i nie wiedzieli co i jak mają załatwić, skutkiem tego nawet jedna z kuracjuszek skierowanych przez Zwiąek Samopomocy Chłopskiej przez 10 dni nie zgłaszała się do lekarza, nie brała zabiegów itd., gdyż nikt jej nie poinformował, gdzie i do kogo ma się zwrócić”' ${ }^{2}$. W większości sudeckich sanatoriów można było również zaobserwować duże zużycie sprzętów, różnorodne, niepasujące do siebie umeblowanie ${ }^{30}$.

Warunki higieniczne nie sprzyjały leczeniu. Na przykład w Dusznikach-Zdroju pościel wymieniana była raz na miesiąc - jeden komplet przypadał więc na jeden turnus ${ }^{31}$. Lepiej było w Kudowie-Zdroju, gdzie wymieniana była dwa razy podczas pobytu, oraz Polanicy-Zdroju, w której pościel zmieniano raz na dwa tygodnie ${ }^{32}$. Kuracjusze często skarżyli się, że ich pokoje nie były sprzątane. Zdarzały się pluskwy i wszy ${ }^{33}$.

${ }^{26}$ Tamże, sygn. 4/2, Sprawozdanie z kontroli lotnej w ZPU Szczawno-Zdrój, 27-28 VIII $1950 \mathrm{r}$.

${ }^{27}$ Tamże, sygn. 4/3, Protokół kontroli działalności DPU Długopole-Zdrój, 22-24 X $1951 \mathrm{r}$.

${ }^{28}$ Tamże, sygn. 4/1, Protokół kontroli lotnej w ZPU Duszniki-Zdrój, 31 VII 1950 r.

29 Tamże, Sprawozdanie z kontroli lotnej w ZPU Duszniki-Zdrój, 25 VIII 1950 r.

30 AAN, ND „PU”, sygn. 4/2, Protokół kontroli w ZPU Świeradów-Zdrój, 24-28 VI 1950 r.; tamże, sygn. 4/4, Protokół kontroli w ZPU Kudowa-Zdrój, 16-20 V oraz 23-26 V $1951 \mathrm{r}$.

${ }^{31}$ Tamże, sygn. 4/1, Protokół kontroli w ZPU Duszniki-Zdrój, 19 V-7 VI 1950 r.

32 Tamże, sygn. 4/4, Protokół lustracji doraźnej w ZPU Kudowa-Zdrój, 21-22 V 1951 r.; APKZ, Uzdrowisko Polanica w Polanicy-Zdroju, sygn. 1/318, Protokół lustracji w Przedsiębiorstwie Państwowym [dalej: PP] Uzdrowisko Polanica, 26 XI $1954 \mathrm{r}$.

33 AAN, ND „PU”, sygn. 4/2, Protokół kontroli w ZPU Szczawno-Zdrój, 10-31 VII 1950 r.; tamże, Sprawozdanie z kontroli lotnej w ZPU Świeradów-Zdrój, 29 VIII 1950 r. 
Oczywiście odnotowywano wyjątki, był to jednak margines, który dotyczył w szczególności wyremontowanych sanatoriów ${ }^{34}$.

Należy dodać, że problemy higieniczne dotyczyły również samych kuracjuszy. Konieczne były tzw. kapiele higieniczne oraz kontrole pod katem wszawicy. Apelowano, aby pacjenci umyli się po podróży, zachowywali czystość w pokojach, toaletach, nie wyrzucali odpadków do muszli klozetowych ${ }^{35}$. Krytyczne uwagi na łamach branżowej prasy dotyczące sytuacji panującej w sudeckich sanatoriach zaczęły pojawiać dopiero od lat 60. Za przykład może posłużyć dość sugestywny opis warunków panujących w Lądku-Zdroju: „Jakież tam znajdą warunki bytowania nieszczęśni "skierowańcy" (pochodne od skazańców)? Jakieś madejowe łoże zasłane tak trochę szarego koloru pościela, piąte z kolei w pięcioosobowym pokoju. Pokój zatęchły i nie wietrzony chyba od czasów, gdy uzdrowisko nawiedzał, jak głoszą kroniki Jan Wolfgang Goethe. Wygody aż nazbyt elementarne”; „Wnętrze "Barbary" przedstawia wręcz przygnębiający widok. Ściany pełne zacieków świadcza o tym, że gmach jest dokładnie zagrzybiony. Wieloosobowe pokoje (4 do 7 łóżek) zatęchłe i wilgotne. Stołówka ciasna i zionąca nie zawsze apetycznymi zapachami, bo kuchnia nie odizolowana. Nie lepiej przestawia się sytuacja w »Tadeuszu«, a nawet w reprezentacyjnym »Wojciechu«" ${ }^{6}$.

Jednocześnie należy podkreślić, że dążono do całkowitego zorganizowania i zagospodarowania pobytu. Po przyjeździe całego turnusu, w pierwszych dniach kuracji, organizowano spotkanie informacyjne, w którym mieli brać udział lekarz uzdrowiskowy oraz przedstawiciel dyrekcji. Podczas zebrania omawiano specyfikę leczenia sanatoryjnego, tryb pobierania zabiegów, a także obowiązki i prawa kuracjusza. Wybierano również radę turnusowa ${ }^{37}$. Była ona specyficznym elementem życia codziennego w uzdrowisku. Stanowiła łącznik i zarazem bufor między dyrekcja, pracownikami a pacjentami. „Do rady turnusu można zgłaszać życzenia i zażalenia wszelkiego rodzaju, np. dotyczace pomieszczenia, wyżywienia, regulaminu, urządzeń uzdrowiskowych itp.”38. Dzięki temu odpowiedzialność i ewentualna krytyka za często katastrofalne warunki spadała na samych kuracjuszy, którzy byli członkami rady,

34 AAN, ND „PU”, sygn. 4/1, Protokół kontroli lotnej w ZPU Duszniki-Zdrój, 31 VII 1950 r.; tamże, sygn. 4/3, Protokół lustracji doraźnej w ZPU Duszniki-Zdrój, 18-21 V $1951 \mathrm{r}$.

${ }^{35}$ S. Cegliński, M. Kalinowski, dz. cyt., s. 13-15.

${ }_{36}$ Z. Żelska, Jest taki sobie Ladek, „Służba Zdrowia” 1962, nr 34, s. 8.

37 AAN, ND „PU”, sygn. 1/3, Instrukcja w sprawie organizacji pracy jednostek organizacyjnych kulturalno-oświatowych w państwowych uzdrowiskach, $1951 \mathrm{r}$.

${ }^{38}$ S. Cegliński, M. Kalinowski, dz. cyt., s. 15-16. 
gdyż to oni, a nie pracownicy uzdrowiska, mieli bezpośredni kontakt z pozostałymi pacjentami. Rada miała również wspomagać referenta kulturalno-oświatowego przy organizacji czasu wolnego. Prowadziła np. kroniki kuracjuszy. Była wybierana przez ogół pacjentów. Zgodnie ze specyfika epoki: „Członkami rady powinni być ludzie poważni, wyrobieni społecznie, zasłużeni przodownicy pracy itp.” W jej skład wchodzili: przewodniczący, dwóch zastępców i starostów ${ }^{39}$.

$\mathrm{Na}$ prawidłowe funkcjonowanie uzdrowisk wpływ miała przede wszystkim sytuacja ekonomiczna kraju i problemy w resorcie zdrowia. Szczególnie dotkliwe były niedobory: zarówno w sprzęcie, jak i produktach żywnościowych. Kwestia wyżywienia była obok stanu infrastruktury najczęściej poruszana zarówno przez dyrektorów poszczególnych uzdrowisk, jak i warszawską administrację. Była ona o tyle istotna, że jakość, ilość jedzenia miała niebagatelny wpływ na przebieg kuracji. „Czym jest żywienie naszych kuracjuszy? Jest to przede wszystkim uzupełnienie zabiegów [...]. Zachodzi pytanie, jak mamy żywić kuracjuszy. Odpowiedź prosta: żywić indywidualnie każdego kuracjusza, zależnie od jego schorzeń i jego organizmu" - stwierdzano na jednej z konferencji w 1948 r. Według założeń dla pacjentów miały być przygotowywane odpowiednie diety. W przypadku Polanicy-Zdroju wyróżniono aż dziesięć różnych propozycji. Teoretycznie zespół pracowników punktów żywienia powinien poradzić sobie z przyrządzeniem takiej ilości posiłków, na przeszkodzie stawały jednak kwestie aprowizacji, odpowiedniej organizacji pracy i właściwego doboru personelu ${ }^{40}$.

Warto zwrócić uwagę, że początkowo wyżywienie było prowadzone w restauracjach „przez dzierżawców na ich własny koszt i ryzyko”. Dopiero wraz z pełnym przekształceniem całego systemu lecznictwa uzdrowiskowego wprowadzono tzw. punkty żywienia, czyli stołówki, w których serwowano jedzenie kuracjuszom. Zamknięcie „luksusowych restauracji” było, podobnie jak likwidacja kurhausów - domów zdrojowych, związane $\mathrm{z}$ nowym charakterem uzdrowisk i idea lecznictwa

${ }^{39}$ Tamże, s. 16; APKZ, Uzdrowisko Długopole w Długopolu-Zdroju, sygn. 16, Kronika turnusów kuracjuszy Uzdrowiska Długopole, 1959 r. Więcej o zadaniach rady turnusowej zob.: AAN, ND „PU”, sygn. 1/3, Instrukcja w sprawie organizacji pracy jednostek organizacyjnych kulturalno-oświatowych w państwowych uzdrowiskach, 1951 r., Załącznik nr 3 do instrukcji w sprawie organizacji pracy jednostek organizacyjnych kulturalno-oświatowych w państwowych uzdrowiskach, 1951 r.; tamże, sygn. 1/4, Instrukcja w sprawie pracy działów kulturalno-oświatowych w państwowych uzdrowiskach, 1952 r., Załącznik nr 1, Regulamin Rady Turnusowej.

${ }^{40}$ Archiwum Państwowe we Wrocławiu (dalej: APWr), Wrocławska Wojewódzka Rada Narodowa (dalej: WrWRN), sygn. 1139, Protokół konferencji dyrektorów i lekarzy uzdrowisk dolnośląskich, Solice-Zdrój, 3-4 X 1948 r. 
sanatoryjnego dla chłopów i robotników, w której nie było miejsca na zamawianie posiłków à la carte ${ }^{41}$. Stołówki zostały zorganizowane w 1948 r. $^{42}$

Wedle założeń wyżywienie miało być „tanie, zdrowe i dobre”, ${ }^{43}$ jednak: „Jakość podawanych posiłków uzależniona jest od surowców i od sumy, jaką możemy poświęcić na ten zakup", a ta przez permanentny kryzys w resorcie była mocno ograniczona ${ }^{44}$. Jednym z najbardziej obrazowych przykładów skutków trudności aprowizacyjnych, a także funkcjonowania rady turnusowej była sytuacja ze Szczawna-Zdroju, która miała miejsce w 1951 r.: „Dnia 15 bm. [sierpnia] po kolacji, której jadłospis obejmował ryż z szynka, jeden z kuracjuszy nazwiskiem Piwowarski wychodząc z sali jadalnej zwrócił się do starosty turnusu ob. Miśkiewicza z zapytaniem gdzie podziała się szynka zapowiedziana na kolację - rozumiejąc, że skoro podano w spisie szynkę z ryżem, na stole pojawią się dwie potrawy, podczas, gdy na kolację było "risotto«. Starosta w odpowiedzi rzucił pytanie: »Przyjechał się Pan obżerać czy leczyć«. Odpowiedź ta wywołała oburzenie kuracjuszy znających ob. Piwowarskiego jako długoletniego więźnia obozów hitlerowskich, a u ob. Piwowarskiego atak nerwowy. Kiedy obecna tam kierowniczka kuchni wyjaśniała kuracjuszom, że wszystkie potrawy podawane na stół kontrolowane są uprzednio przez lekarza zakładowego, ob. Załęska zapytała: »czy ten doktor Bazała próbuje również śmietanę podawaną na podwieczorek, która od kilku dni nie nadaje się do konsumpcji?". Awantura w jadalni dotycząca jakości wyżywienia miała swój ciąg dalszy - włączył się w nią m.in. wicedyrektor uzdrowiska oraz pozostali kuracjusze ${ }^{45}$. Jadłospisy nie mogły być zaplanowane $\mathrm{z}$ wyprzedzeniem z powodu problemów z dostawami. Tak było m.in. w Długopolu-Zdroju czy Polanicy-Zdroju ${ }^{46}$. Zdarzały się przypadki, że dla kuracjuszy

${ }^{41}$ APWr, WrWRN, sygn. 1140, Sprawozdanie Zarządu Państwowych Uzdrowisk Dolnośląskich za 1947 r.; Protokół posiedzenia Komisji Specjalnej do spraw uzdrowisk dolnośląskich, 7 VIII $1948 \mathrm{r}$.

${ }^{42}$ AAN, Ministerstwo Zdrowia, sygn. 49, Pismo ND „PU” do Ministerstwa Zdrowia, Gabinetu Ministra, 12 XI 1948 r.

43 Tamże.

${ }^{44}$ APWr, WrWRN, sygn. 1139, Protokół konferencji dyrektorów i lekarzy uzdrowisk dolnoślaskich, Solice-Zdrój, 3-4 X 1948 r.

${ }^{45}$ AAN, ND „PU”, sygn. 4/6, Sprawozdanie komisji delegowanej do Szczawna-Zdroju, 24-25 VIII 1951 r., w celu przeprowadzenia dochodzeń w związku z depesza wysłana przez kuracjuszy sanatorium $\mathrm{nr} 5$.

${ }^{46}$ Tamże, sygn. 4/3, Sprawozdanie z lustracji doraźnej w ZPU Długopole-Zdrój, 24 V 1951 r.; tamże, sygn. 4/5, Protokół lustracji doraźnej w ZPU Polanica-Zdrój, 15-17 V $1951 \mathrm{r}$. 
brakowało jedzenia ${ }^{47}$. Tak sytuację w Przerzeczynie-Zdroju w 1952 r. opisywał kierownik biura usług: ,jeżeli chodzi o zaopatrzenie, to uległo ono istotnie pogorszeniu po wprowadzeniu zmniejszonych przydziałów mięsa i tłuszczu, przy całkowitym braku jajek, sera tylżyckiego, kapusty" ${ }^{48}$. Problemy aprowizacyjne pojawiały się przez cały omawiany okres. Dotyczyły przede wszystkim zbyt małej ilości tłuszczów, jarzyn, mleka ${ }^{49}$. W szczególności brakowało warzyw i urozmaiconych surówek. Dotyczyło to m.in. Kudowy-Zdroju, Polanicy-Zdroju, Lądka-Zdroju ${ }^{50}$. Sytuacja nie uległa poprawie w kolejnym dziesięcioleciu. Krytycznie o wyżywieniu w Lądku-Zdroju wypowiadała się m.in. dziennikarka branżowej „Służby Zdrowia” z 1962 r.: „Surówek mało, kompoty żałosne. Mankamenty te wynikają rzekomo stąd, że stołówki muszą się zaopatrywać w produkty wyłacznie w Bystrzycy"51. Problemy dostrzegały dyrekcje uzdrowisk, podając przy tym abstrakcyjne usprawiedliwienia, m.in. niesprzyjające warunki atmosferyczne, które miały występować w całym kraju ${ }^{52}$. Faktycznie wobec uspołecznionego handlu i socjalistycznej gospodarki niewiele mogły zrobić. W obliczu walki z niedoborami nakazywano np., by zakłady samodzielnie kisiły kapustę (,Pamiętać należy, iż racjonalnie ukiszona kapusta jest prawie jedynym źródłem witaminy $\mathrm{C}$ w okresie zimowym" ${ }^{53}$ ). Ratunkiem miała być również własna hodowla i uprawa. Były jednak miejscowości, w których kuracjusze mogli być zadowoleni z serwowanego jedzenia. Do chlubnych, ale jednak wyjątków należały uzdrowiska w Świeradowie-Zdroju oraz Dusznikach-Zdroju ${ }^{54}$. Stołówki borykały się również z brakiem kompletnej zastawy stołowej, sprzętu niezbędnego do przygotowywania posiłków. Skutkowało to absurdami niczym z filmów Barei. Na przykład w Kudowie-Zdroju dział żywienia

${ }^{47}$ Tamże, sygn. 4/2, Sprawozdanie z kontroli lotnej w ZPU Świeradów-Zdrój, 29 VIII $1950 \mathrm{r}$.

48 Tamże, sygn. 4/7, Protokół narady produkcyjnej pracowników DPU Przerzeczyn-Zdrój, 18 II 1952 r.

49 APWr, WrWRN, sygn. 1140, Sprawozdanie Zarządu Państwowych Uzdrowisk Dolnośląskich za $1947 \mathrm{r}$.

${ }^{50}$ AAN, ND „PU”, sygn. 4/4, Protokół lustracji doraźnej w ZPU Kudowa-Zdrój, 21-22 V 1951 r.; tamże, Sprawozdanie z lustracji doraźnej w ZPU Lądek-Zdrój, 23 V 1951 r.; tamże, sygn. 4/5, Protokół lustracji doraźnej w ZPU Polanica-Zdrój, 15-17 V $1951 \mathrm{r}$.

${ }^{51}$ Z. Żelska, dz. cyt., s. 8.

${ }^{52}$ APKZ, Uzdrowisko Lądek-Długopole, sygn. 46, Pismo do CZU, 22 IX 1965 r.

${ }^{53}$ AAN, ND „PU”, sygn. 1/5, Pismo w sprawie kiszenia kapusty na okres zimowy, 26 VIII $1952 \mathrm{r}$.

${ }_{54}$ Tamże, sygn. 4/1, Protokół kontroli lotnej w ZPU Duszniki-Zdrój, 31 VII 1950 r.; tamże, sygn. 4/6, Protokół lustracji doraźnej w ZPU Świeradów-Zdrój, 31 V-1 VI $1951 \mathrm{r}$. 
na pięć sanatoriów posiadał jedną obieraczkę do ziemniaków, czego konsekwencją była konieczność regulacji czasu, jaki miał być poświęcony na obieranie kartofli ${ }^{55}$. Oprócz problemów aprowizacyjnych najczęstszym uchybieniem w tzw. punktach żywienia był brak higieny ${ }^{56}$. „Kuracjusze skarżyli się na brudy w stołówce sanatorium nr 2. Jeden z przedstawicieli Rady Turnusowej znalazł w zupie stonogę, którą jako dowód przyniósł na zebranie. W potrawach często znajduja się włosy. Kubeczki sa niedomywane (ślady szminki), w stołówce obrusy są brudne, kelnerki opryskliwe, półgodzinne przerwy między daniami" - pisano w protokole kontroli uzdrowiska w Dusznikach-Zdroju ${ }^{57}$.

Fatalne warunki higieniczne i braki w infrastrukturze oprócz uchybień natury estetycznej miały również konsekwencje dla zdrowia kuracjuszy. Za przykład może posłużyć sytuacja z sanatorium w Dusznikach-Zdroju, które było przeznaczone dla osób cierpiących na schorzenia kardiologiczne: „Wyposażenie wewnętrzne Pawilonu nr II jest raczej mierne, sam budynek wymagałby kapitalnego remontu. Winda w tym budynku jest stale nieczynna, co również przy trzech piętrach nie stwarza odpowiednich warunków dla chorych sercowo"58. Także zawilgocenie i brak wentylacji w kabinach kapielowych nie pozostawało bez wpływu na stan kuracjuszy ${ }^{59}$. W Szczawnie-Zdroju, uzdrowisku specjalizujacym się w leczeniu górnych dróg oddechowych, w tym astmy, materace w jednym z sanatoriów wypełnione były trawa „ze względu na zużycie, przy poruszaniu, unosi się z nich tuman kurzu"60. Negatywne skutki mógł mieć również brak zegarów odmierzających czas kapieli oraz dzwonków alarmowych ${ }^{61}$. Zdarzały się też wypadki, że w gabinetach lekarskich nie było bieżącej wody. Taka sytuacja miała miejsce w Długopolu-Zdroju, gdzie całe uzdrowisko cierpiało na ciagły brak wody. Uniemożliwiało to

${ }^{55}$ APKZ, Uzdrowisko Kudowa w Kudowie-Zdroju, sygn. 5/33, Zarządzenie wewnętrzne nr 3/56, 18 VII $1956 \mathrm{r}$.

56 AAN, ND „PU”, sygn. 4/2, Protokół kontroli w ZPU Szczawno-Zdrój, 10-31 VII $1950 \mathrm{r}$.

${ }^{57}$ Tamże, sygn. 4/3, Sprawozdanie z podróży służbowej do DPU Duszniki 19-22 VIII 1951 r. Robaki znajdowano również w posiłkach w Przerzeczynie-Zdroju; APKZ, Uzdrowisko Przerzeczyn w Przerzeczynie-Zdroju, sygn. 3, Protokół narady roboczej, 17 II $1958 \mathrm{r}$.

58 AAN, ND „PU”, sygn. 4/1, Protokół kontroli lotnej w ZPU Duszniki-Zdrój, 31 VII $1950 \mathrm{r}$.

59 Tamże, Protokół kontroli w ZPU Duszniki-Zdrój, 19 V-7 VI 1950 r.

${ }^{60}$ AAN, ND „PU”, sygn. 4/7, Sprawozdanie do protokołu kontroli DPU Szczawno-Zdrój, 2-11 V 1952 r.

${ }^{61}$ Tamże, sygn. 4/4, Protokół z kontroli działalności DPU Lądek-Zdrój, 16-20 X $1951 \mathrm{r}$. 
egzekwowanie podstawowych zasad higieny. Do remontu komunalnych wodociagów przystapiono dopiero $\mathrm{w} 1962 \mathrm{r}^{62} \mathrm{Z}$ problemem nie zdołano się jednak uporać - w świetle dokumentacji z 1969 r. nadal na wyższe kondygnacje budynków woda nie docierała ${ }^{63}$.

Kwestią poruszaną właściwie we wszystkich protokołach kontrolnych był brud w sanatoryjnych pokojach, korytarzach, łazienkach. Jako ilustracja problemu może posłużyć przykład ze Świeradowa-Zdroju: „Pawilony sanatoryjne przeważnie zaniedbane - pomieszczenia za późno sprzątane. Uderza brak troski o wygląd estetyczny. Na ścianach wiszą nieaktualne hasła, plakaty, stare gazetki. Wszędzie brak napisów informacyjnych [...]. Powietrze zanieczyszczone zapachami z brudnych ubikacji" - tak opisywano sanatorium nr $1^{64}$. Wśród nielicznych wyjątków wymienić można Polanica-Zdrój oraz Lądek-Zdrój ${ }^{65}$. Szeroko pojęte braki dotyczyły również tzw. działów zabiegowych. Bardzo często ich stan odbiegał od przyjętych standardów. Najczęstszym uchybieniem tu także był brud. Uzdrowiska nie dysponowały też niezbędnymi, podstawowymi urządzeniami, jak termometry czy zegary. Brak klepsydr w łazienkach uniemożliwiał dokładnie określenie czasu wyjścia z kapieli, która ordynowana była na od 10 do 20 minut. Takie sytuacje miały miejsce w Świeradowie-Zdroju, Długopolu-Zdroju oraz Dusznikach-Zdroju czy Lądku-Zdroju ${ }^{66}$. Brakowało również odpowiedniego sprzętu lekarskiego. W Dusznikach-Zdroju przy zabiegach borowinowych nie używano prześcieradeł, a borowinę nałożona na ciało przykrywano jedynie cerata. Powodem takiego postępowania była po prostu „niemożność

62 Tamże, sygn. 4/3, Protokół kontroli działalności DPU Długopole-Zdrój, 22-24 X 1951 r.; APKZ, Uzdrowisko Długopole w Długopolu-Zdroju, sygn. 8, Problematyka do analizy działalności PP Uzdrowisko Długopole za okres 1959-1961.

${ }^{63}$ APKZ, Uzdrowisko Lądek-Długopole, sygn. 54, Protokół sporządzony w związku z przeprowadzona przez Zjednoczenie „Uzdrowiska Polskie” kontrolą kompleksowa w Państwowego Przedsiębiorstwa Uzdrowiskowego Lądek-Długopole, 22 X 1969 r.

${ }^{64}$ AAN, ND „PU”, sygn. 4/3, Sprawozdanie z podróży służbowej odbytej do Cieplic, Świeradowa, Szczawna, Polanicy, 5-11 VII [1951 r.?]. Brudno miało być również m.in. w Szczawnie-Zdroju; tamże, sygn. 4/6, Protokół z kontroli doraźnej w ZPU Szczawno-Zdrój, 23-24 IV $1951 \mathrm{r}$.

${ }_{65}$ Tamże, sygn. 4/3, Sprawozdanie z podróży służbowej odbytej do Cieplic, Świeradowa, Szczawna, Polanicy, 5-11 VII [1951 r.?]; tamże, sygn. 4/5, Protokół lustracji doraźnej w ZPU Polanica-Zdrój, 15-17 V 1951 r.; tamże, sygn. 4/4, Sprawozdanie z lustracji doraźnej w ZPU Lądek-Zdrój, 23 V 1951 r.

${ }^{66}$ Tamże, sygn. 4/1, Sprawozdanie z kontroli lotnej w ZPU Duszniki-Zdrój, 25 VIII 1950 r.; tamże, sygn. 4/4, Protokół kontroli działalności DPU Lądek-Zdrój, 16-20 X 1951 r.; Braki Świeradowa-Zdroju, „Służba Zdrowia” 1952, nr 10, s. 7; AAN, ND „PU”, sygn. 4/3, Protokół kontroli działalności DPU Długopole-Zdrój, 22-24 X $1951 \mathrm{r}$. 
zakupu prześcieradeł"67. Ubytki w narzędziach lekarskich dotykały też Świeradów-Zdrój. W uzdrowisku nie było wzierników, sprzętu laryngologicznego ${ }^{68}$. Z uwagi na brak lampy do rentgena aparat był nieczynny. Miało to wpływ na jakość usług, prawidłowe diagnozowanie pacjentów. Z kolei w kabinach kapielowych w Długopolu-Zdroju nie było odpowiedniej wentylacji, a w Dusznikach-Zdroju płatami odpadała farba olejna ${ }^{69}$.

Przyczyn takiego stanu rzeczy należy szukać przede wszystkim w problemach gospodarczych kurortów, ich niedofinansowaniu. W pewnym uproszczeniu można stwierdzić, że od końca wojny do lat 60., 70. w uzdrowiskach nie przywiazywano wagi do stanu infrastruktury. Nie przeprowadzano modernizacji, kapitalnych remontów. Szeroko pojęte braki w zaopatrzeniu występowały we wszystkich sudeckich ośrodkach przez cały analizowany okres, co było spowodowane specyfiką socjalistycznej gospodarki. Były one szczególnie dotkliwe i widoczne przy pozyskiwaniu kuracjuszy zagranicznych, kiedy konieczne było podniesienie standardu. Brakowało tak prozaicznych wydawałoby się rzeczy, jak mydła czy ręczniki. Niedobory w sprzęcie zabiegowym były spowodowane również brakiem krajowych linii produkcyjnych. Kraje bloku wschodniego nie zawsze wytwarzały odpowiednie części, a sprowadzanie ich z „krajów zachodnich” było skomplikowanym i długim procesem ${ }^{70}$.

Szeroko pojęta i różnie rozumiana estetyka w pomieszczeniach sanatoryjnych pozostawiała wiele do życzenia. Nie przywiązywano wagi do dekoracji pokoi, jadalni. W większości uzdrowisk brakowało kwiatów, tak było m.in. w Czerniawie-Zdroju, Cieplicach-Zdroju, Kudowie-Zdroju czy Polanicy-Zdroju ${ }^{71}$. Często było to spowodowane zwykłym marnotrawstwem. „W sanatoriach brak jakichkolwiek dekoracji, szczególnie kwietnych (oprócz kilku palm w sanatorium nr 1), gdy jednocześnie w ogrodnictwie przekwita bezcelowo masa różnych kwiatów”; „Brak zupełny troski o estetykę wnętrz, np. w Sanatorium nr 1, przed gabinetem lekarskim stoi dla oczekujących kuracjuszy 8 krzeseł. Przy tym

67 AAN, ND „PU”, sygn. 4/1, Protokół kontroli w ZPU Duszniki-Zdrój, 19 V-7 VI $1950 \mathrm{r}$.

68 Tamże, sygn. 4/6, Protokół kontroli działalności DPU Świeradów-Zdrój, 18 VI-4 VII $1951 \mathrm{r}$.

69 Tamże, sygn. 4/1, Protokół kontroli w ZPU Duszniki-Zdrój, 19 V-7 VI 1950 r.; tamże, sygn. 4/3, Protokół kontroli działalności DPU Długopole-Zdrój, 22-24 X 1951 r.

${ }^{70}$ AAN, CZU, sygn. 8/3, Protokół narady dyrektorów przedsiębiorstw uzdrowiskowych, 15 XI $1966 \mathrm{r}$.

${ }^{71}$ AAN, ND „PU”, sygn. 4/3, Protokół kontroli planowej w ZPU Czerniawa-Zdrój, 8-15 V 1951 r.; tamże, Protokół kontroli DPU Cieplice-Zdrój, 30 XI-9 XII 1951 r.; tamże, sygn. 4/4, Protokół kontroli w ZPU Kudowa-Zdrój, 16-20 V oraz 23-26 V 1951 r.; tamże, sygn. 4/5, Protokół lustracji doraźnej w ZPU Polanica-Zdrój, 15-17 V 1951 r. 
6 z nich jest zupełnie różnych rodzajów i kolorów (Gdy we wszelkich nieużytkowanych pomieszczeniach jest masa różnych nawet luksusowych mebli). To samo odnosi się do porządku. Np. na korytarzu parteru Sanatorium nr 1, w szafie ściennej, stale nieraz przez kilka dni z rzędu, stały talerze z resztkami jedzenia, odłamkami chleba, bułki, butelki itp." - tak opisywano Szczawno-Zdrój ${ }^{72}$. W pokojach oraz korytarzach powinny znajdować się regulaminy opisujace np. pory posiłków, miejsca, gdzie pacjenci mogą załatwić daną sprawę oraz - jak to określano - „ustalające tryb życia” w uzdrowisku. Nie we wszystkich sanatoriach one jednak były ${ }^{73}$.

Wpływ na pobyt kuracjuszy w uzdrowiskach miał również brak należycie przeszkolonej kadry pracowniczej. „Sanatoria uskarżają się jeszcze ciagle na słaby dopływ sił fachowych. Przeważnie zgłasza się do pracy element zupełnie surowy, dopiero szkolony na kursach" - relacjonowano na łamach „Służby Zdrowia” w 1950 r. ${ }^{74}$ Lekarze ze względu na warunki pracy, niskie uposażenie, trudności lokalowe nie chcieli pracować w uzdrowiskach ${ }^{75}$. W Długopolu-Zdroju jako przyczynę braku chętnych wymieniano również obawę przed zarażeniem żółtaczką ${ }^{76}$. Wiele specjalistycznych sprzętów nie mogło być użytkowanych z powodu braku fachowców. Tak było np. w Dusznikach-Zdroju, gdzie nie było personelu, który obsługiwałby aparaty rentgenowski i EKG ${ }^{77}$. Podobna sytuacja miała miejsce w Szczawnie-Zdroju, gdzie nieczynne były dwa aparaty rentgenowskie ${ }^{78}$. Zdarzało się, że uzdrowiska zatrudniały lekarzy tuż po studiach. Często także tzw. biały personel nie był należycie przeszkolony i doświadczony. Na przykład w Szczawnie-Zdroju zastrzyki robione były przez sanitariuszki: „sa one jeszcze siłami bardzo słabo kwalifikowanymi i np. jedna z nich zapytana w toku kontroli - po co gotuje strzykawki odpowiedziała dosłownie: »żeby nie było dezynfekcji«"79. W Świeradowie-Zdroju pracowały niewykwalifikowane kapielowe,

72 Tamże, sygn. 4/2, Protokół kontroli w ZPU Szczawno-Zdrój, 10-31 VII 1950 r.

${ }_{73}$ Tamże, sygn. 4/3, Protokół lustracji doraźnej w ZPU Duszniki-Zdrój, 18-21 V 1951 r.; tamże, sygn. 4/1, Sprawozdanie z kontroli lotnej w ZPU Duszniki-Zdrój, 25 VIII $1950 \mathrm{r}$.

${ }^{74}$ L. Wolanowski, Jeden dzień w Polanicy, „Służba Zdrowia” 1950, nr 21, s. 4.

75 A.Kazior,Zapewnićuzdrowiskom dobrychlekarzy,„SłużbaZdrowia”1962,nr2, s. 3.

${ }^{76}$ APKZ, Uzdrowisko Długopole w Długopolu-Zdroju, sygn. 14, Protokół zdawczo-odbiorczy z przekazania majątku PP Uzdrowisko Długopole dla PP Uzdrowisko Lądek, 4 II 1965 r.

77 AAN, ND „PU”, sygn. 4/1, Protokół kontroli w ZPU Duszniki-Zdrój, 19 V-7 VI $1950 \mathrm{r}$.

78 Tamże, sygn. 4/2, Protokół kontroli w ZPU Szczawno-Zdrój, 10-31 VII 1950 r.

79 Tamże. 


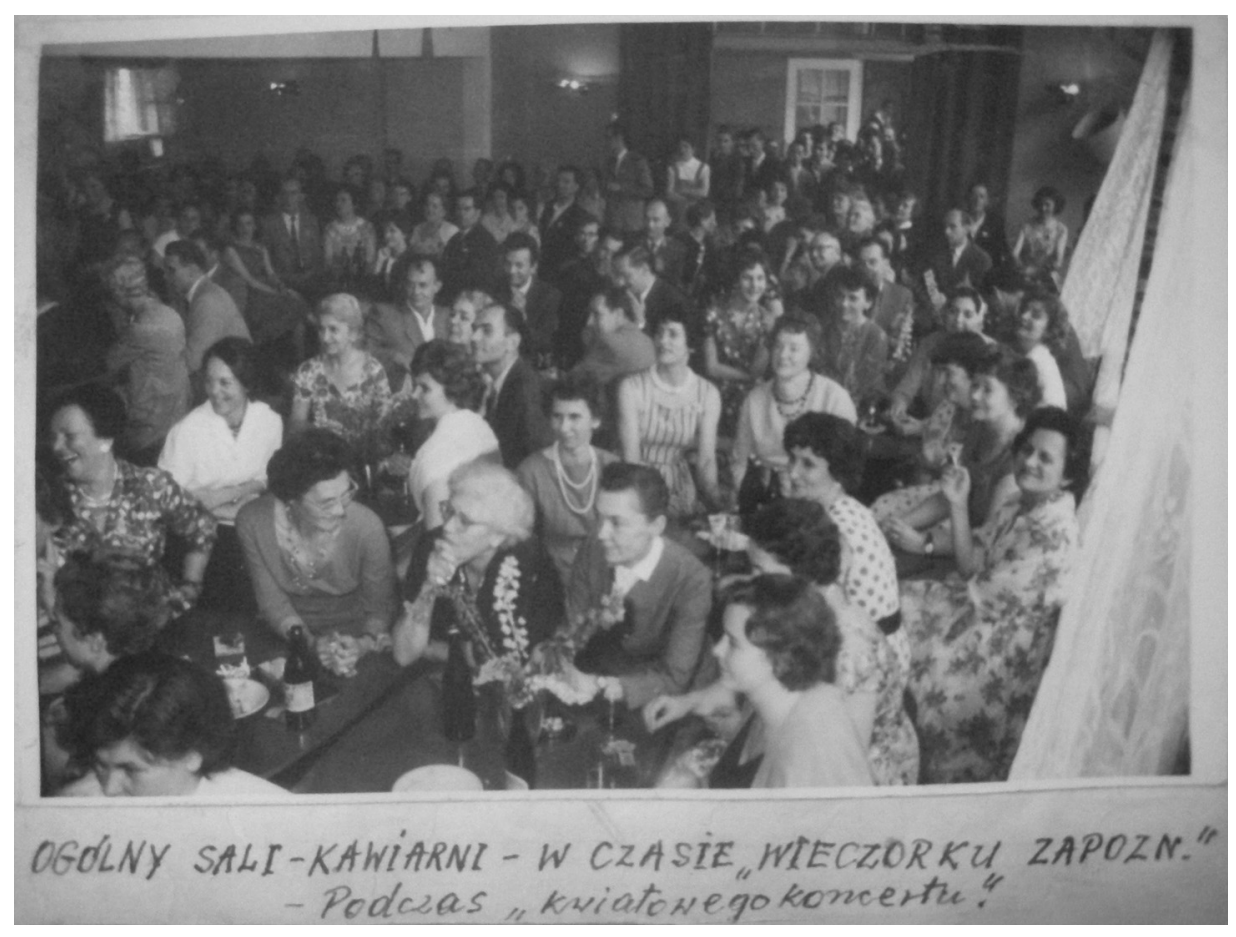

Il. 2. Fragment kroniki kuracjuszy z Długopola-Zdroju - wieczorek zapoznawczy, 1961 r.; APKZ, Uzdrowisko Długopole w Długopolu-Zdroju, sygn. 17, Kronika turnusów kuracjuszy Uzdrowiska Długopole, $1961 \mathrm{r}$.

z uwagi na „brak w terenie tego rodzaju sił”80. Również uzdrowisko w Lądku-Zdroju borykało się z niedoborami personelu. Lekarzy i pielęgniarek było za mało, przez co byli oni przeciążeni praca. Nie pozostawało to bez wpływu na opiekę nad kuracjuszami ${ }^{81}$. W Przerzeczynie-Zdroju w ogóle nie było stałego lekarza ${ }^{82}$. Niedostateczna opieka lekarska i pielęgniarska skutkowała m.in. brakiem nadzoru nad stanem sanitarnym, jakością wyżywienia i przede wszystkim nad zalecanymi zabiegami ${ }^{83}$.

Nie samymi zabiegami żył ówczesny kuracjusz, pacjentom należało zorganizować także czas wolny. Dyrekcje uzdrowisk musiały zapewnić „odpowiednią" rozrywkę, określaną jako akcja kulturalno-oświatowa.

80 AAN, ND „PU”, sygn. 4/2, Pismo ND „PU” do ZPU Świeradów-Zdrój, 5 IX 1950 r.

${ }^{81}$ Tamże, sygn. 4/4, Sprawozdanie z lustracji doraźnej w ZPU Lądek-Zdrój, 23 V $1951 \mathrm{r}$.

82 Tamże, sygn. 4/7, Sprawozdanie do protokołu kontroli DPU Przerzeczyn-Zdrój, 14-15, 17, 24 XI $1952 \mathrm{r}$.

${ }^{83}$ Tamże, Sprawozdanie z podróży służbowej do Świeradowa-Zdroju, 3-13 IX $1952 \mathrm{r}$. 
Miała być zorganizowana tak, ,aby każdego dnia w godzinach popołudniowych i wieczornych kuracjusze mieli czas urozmaicony imprezami artystycznymi, pogadankami na tematy społeczne i ogólnokształcące, wycieczkami i spacerami, głośnym czytaniem itp." ${ }^{84}$. Ten aspekt życia codziennego w sanatoriach był wyjątkowo często i intensywnie wykorzystywany do celów propagandowych. Zgodnie z językiem komunistycznej propagandy w artykułach opisywano, jak „kuracjusze między zabiegami leczniczymi, wiele czasu spędzają $\mathrm{w}$ świetlicach przy grze $\mathrm{w}$ domino, szachy, czy warcaby. W każdym sanatorium [w Polanicy-Zdroju - K.W.] znajduje się pianino, fortepian lub inne instrumenty muzyczne, z których pacjenci moga korzystać"s5. Trzeba jednak przyznać, że wyobrażenie sobie małorolnego chłopa, skierowanego do sanatorium przez Zwiąek Samopomocy Chłopskiej, który w świetle relacji lekarzy nie radził sobie z podstawowymi czynnościami higienicznymi, grającego na fortepianie lub w szachy wymaga pewnego wysiłku. Podobnie beztroski klimat miał panować we wszystkich sudeckich uzdrowiskach: „Jest duża biblioteka, jest kawiarnia, sa koncerty, można odbywać sielskie spacery - no właściwie jest wszystko co dusza zapragnie (jest kino i to bardzo porządne choć objazdowe)" - relacjonował kuracjusz na łamach „Służby Zdrowia” w $1958 \mathrm{r} .{ }^{86}$ Rzeczywistość, podobnie jak w pozostałych aspektach życia codziennego $\mathrm{w}$ uzdrowisku, znacznie rozmijała się z propagandowym, wyidealizowanym obrazem.

Osobami odpowiedzialnymi za szeroko pojętą rozrywkę byli referenci kulturalno-oświatowi, szkoleni w Cieplicach-Zdroju. Musieli być zatrudnieni we wszystkich uzdrowiskach ${ }^{87}$. Znaczenie akcji kulturalno-oświatowych było związane z nowym modelem uzdrowisk, jaki ukształtował się na przełomie lat 40. i 50.: „Referenci kulturalno-oświatowi są zdobycza Polski Ludowej, wyrazem jej troski o rozwój kulturalny obywatela [...]. Ze zmianą składu socjalnego zmieniła się atmosfera. Miejsce bezmyślnej zabawy zajęła zdrowa cisza domów leczniczych. Społeczno-oświatowa praca w uzdrowisku polega na opiece nad chorym i na pracy nad uspołecznieniem pracowników, nad zespołem świetlicowym, najczęściej miejscowym. Całokształt działalności kulturalno-oświatowej zmierza do pogłębienia socjalistycznego współżycia" ${ }^{88}$. Jednym z elementów akcji

${ }^{84}$ Uzdrowiska w stużbie świata pracy, „Służba Zdrowia” 1952, nr 25, s. 7.

${ }^{85}$ Z. Okuniewski, dz. cyt., s. 4.

${ }^{86}$ W. Rodan, List $z$ Dtugopola, „Służba Zdrowia” 1958, nr 23, s. 6.

87 Uzdrowiska $w$ stużbie świata pracy..., s. 7; AAN, ND „PU”, sygn. 1/1, Biuletyn Wewnętrzny nr 1, 20 III 1949 r.

88 A. Zielonka-Chełmińska, Znaczenie akcji kulturalno-oświatowej $w$ uzdrowiskach, „Balneologia Polska” 1, 1951, s. 225. 
kulturalno-oświatowych były pogadanki i referaty, które traktowały najczęściej o bieżącej sytuacji politycznej oraz - ze względu na specyfikę pobytu w uzdrowisku - również o metodach leczenia, rodzajach zabiegów itd. ${ }^{89}$ Tematyka spotkań była podobna we wszystkich uzdrowiskach. W latach 50. koncentrowała się na szeroko pojętej problematyce „walki o pokój”, socjalizmu, przebudowy ustroju oraz walorach Dolnego Ślaska jako nierozłącznej części tzw. Ziem Odzyskanych ${ }^{90}$. W późniejszym okresie, po październikowej odwilży, zrezygnowano z tak nachalnej propagandy. Pomimo zmian prelekcje polityczno-ekonomiczne pozostały jednak częścią tzw. zajęć świetlicowych.

Jak już wspomniano, we wszystkich uzdrowiskach miały znajdować się dobrze urządzone świetlice, biblioteki. Jednak wzorcowe założenia teoretyczne, w świetle których kuracjusze wolny czas mieli spędzać z książką w ręku, po raz kolejny rozmijały się z rzeczywistościa. Odnosiło się to przede wszystkim do ludności chłopskiej. Szerzenie czytelnictwa było jednym z głównych problemów, z jakimi musieli zmierzyć się referenci ${ }^{91}$. Na przeszkodzie stawał również brak gazet oraz gier ${ }^{92}$. $\mathrm{Z}$ uwagi na profil kuracjuszy przebywających w uzdrowiskach działy kulturalno-oświatowe miały zajmować się szkoleniami analfabetów i półanalfabetów. Organizowano np. głośne czytanie ${ }^{93}$. Na marginesie należy dodać, że dużą uwagę przywiązywano do tzw. radiofonizacji sanatoriów oraz z czasem do instalowania w nich telewizorów ${ }^{94}$.

Pomimo przedstawiania uzdrowisk jako miejsc przeznaczonych tylko do celów leczniczych, organizowano w nich również imprezy towarzyskie, takie jak wieczorki zapoznawcze, pożegnalne, dancingi. Warto zwrócić uwagę na wybory „Miss Żółtaczka”, które przeprowadzano w Długopolu-Zdroju ${ }^{95}$.

89 P. Sroka, Wczasy z kaowcem, „Pamięć i Przyszłość” 2009, nr 2, s. 30.

90 AAN, ND „PU”, sygn. 4/4, Protokół lustracji doraźnej w ZPU Kudowa-Zdrój, 21-22 V 1951 r.; tamże, sygn. 4/6, Protokół kontroli działalności DPU Świeradów-Zdrój, 18 VI-4 VII $1951 \mathrm{r}$.

${ }^{91}$ A. Zielonka-Chełmińska, dz. cyt., s. 225. O popularyzacji czytelnictwa jako jednego z głównych zadań pracy kulturalno-oświatowej zob. też P. Sroka, Wczasy $z$ kaowcem..., s. 30 .

92 AAN, ND „PU”, sygn. 4/3, Sprawozdanie z podróży służbowej odbytej do Cieplic, Świeradowa, Szczawna, Polanicy, 5-11 VII [1951 r.?]; APKZ, Uzdrowisko Lądek-Długopole, sygn. 46, Pismo Najwyższej Izby Kontroli do dyrektora Państwowego Uzdrowiska Lądek-Długopole, 20 VIII 1965 r.

${ }^{93}$ AAN, ND „PU”, sygn. 4/6, Protokół kontroli działalności DPU Świeradów-Zdrój, 18 VI-4 VII 1951 r.; tamże, Protokół lustracji doraźnej w ZPU Świeradów-Zdrój, $31 \mathrm{~V}-1$ VI $1951 \mathrm{r}$.

${ }_{94}$ Polanica, „Wiadomości Uzdrowiskowe” 1958, nr 4, s. 92.

95 APKZ, Uzdrowisko Długopole w Długopolu-Zdroju, sygn. 16, Kronika turnusów kuracjuszy Uzdrowiska Długopole, 1959 r. 
Sytuacja kuracjuszy w tym uzdrowisku (po zmianie profilu na leczenie chorych na wirusowe zapalenie wątroby) była specyficzna - ze względu na ryzyko zarażenia mieli bezwzględny zakaz opuszczania uzdrowiska, musieli wystrzegać się wysiłku fizycznego, co wykluczało również zbyt forsowne tańce ${ }^{96}$. W programach kulturalno-oświatowych znajdowało się miejsce dla występów teatralnych, artystycznych, które wystawiane były przez trupy amatorskie z okolicznych miejscowości, „Artos” oraz tzw. zespoły świetlicowe uzdrowisk ${ }^{97}$. Działały w nich również grupy złożone z pracowników, tak było m.in. w Cieplicach-Zdroju ${ }^{98}$. Zabronione regulaminem sanatoryjnym były za to gry hazardowe ${ }^{99}$. Tym samym odcięto się od uzdrowiskowej tradycji oddawania się rozrywce w „pałacach hazardu” ${ }^{100}$. Podobnie jak przed wojna, organizowano za to wycieczki, najczęściej do sasiednich miejscowości uzdrowiskowych ${ }^{101}$.

Program zajęć kulturalno-oświatowych opracowywano w systemie miesięcznym, uzależniony on był m.in. od pory roku i aktualnej sytuacji politycznej ${ }^{102}$. Jako przykład działalności w okresie stalinizmu można przytoczyć program imprez realizowany w Długopolu-Zdroju we wrześniu i październiku 1951 r.: „Socjalistyczna przebudowa wsi polskiej, walka o wykonanie planu 6-letniego, pogadanka o rolnictwie, walka o pokój, pogadanka o leczeniu w sanatoriach, trzy wieczory dyskusyjne na temat skupu zboża, walka ze spekulacja, kolektywizacja wsi, dwie prasówki z 10 dni, 3 razy urządzono wycieczki do Dusznik[-Zdroju], Polanicy[-Zdroju], Międzylesia [...]. Dzień Wojska Polskiego

96 Tamże.

97 AAN, ND „PU”, sygn. 4/5, Protokół kontroli działalności DPU Polanica-Zdrój, 6-20 VIII 1951 r. „Artos” - Państwowa Organizacja Imprez Artystycznych, powstała w 1950 r. Działalność zakończyła w 1955 r. Jej poprzedniczka, od 1948 r., była Społeczna Organizacja Imprez Artystycznych „Artos”; D. Jarosz, „Masy pracujace przede wszystkim”. Organizacja wypoczynku w Polsce 1945-1956, Warszawa-Kielce 2003, s. 78.

98 AAN, ND „PU”, sygn. 4/3, Sprawozdanie z podróży służbowej odbytej do Cieplic, Świeradowa, Szczawna, Polanicy, 5-11 VII [1951 r.?]

99 S. Cegliński, M. Kalinowski, dz. cyt., s. 57.

100 G. Balińska, Uzdrowiska dolnoślaskie. Problemy rozwoju i ochrony wartości kulturowych do II wojny światowej, Wrocław 1991, s. 90.

101 AAN, ND „PU”, sygn. 4/1, Protokół kontroli lotnej w ZPU Duszniki-Zdrój, 31 VII 1950 r.; tamże, sygn. 4/5, Protokół kontroli działalności DPU Polanica-Zdrój, 6-20 VIII $1951 \mathrm{r}$.

102 Szerzej o planie pracy kulturalno-oświatowej zob.: tamże, sygn. 1/3, Instrukcja w sprawie organizacji pracy jednostek organizacyjnych kulturalno-oświatowych w państwowych uzdrowiskach, 1951 r.; tamże, sygn. 1/4, Instrukcja w sprawie pracy działów kulturalno-oświatowych w państwowych uzdrowiskach, 1952 r.; A. Zielonka-Chełmińska, dz. cyt., s. 225. 


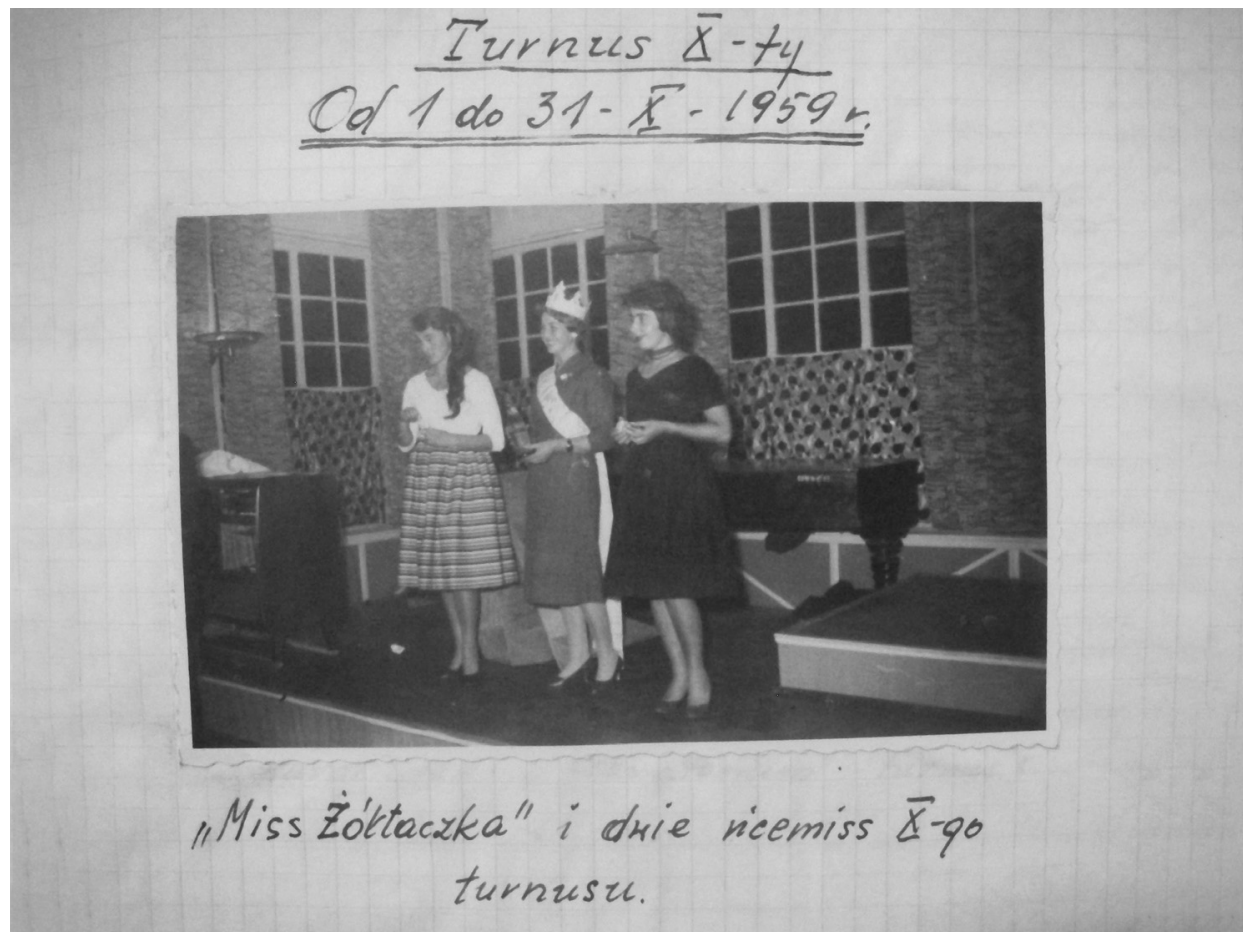

Il. 3. Fragment kroniki kuracjuszy z Długopola-Zdroju, przedstawiający laureatki wyborów „Miss Żółtaczka”, 1959 r.; APKZ, Uzdrowisko Długopole w Długopolu-Zdroju, sygn. 16, Kronika turnusów kuracjuszy Uzdrowiska Długopole, 1959 r.

pogadanka, przyjaźń polsko-radziecka, rocznica śmierci Chopina, socjalistyczna budowa wsi polskiej, ZSRR kraj zwycięskiego socjalizmu, 1 raz film krótkometrażowy wyświetlany, impreza artosu [sic!] „Żywe Słowo", akademia o przyjaźni polsko-radzieckiej" ${ }^{103}$. Widoczne jest, że na tzw. zajęciach świetlicowych koncentrowano się przede wszystkim na przekazywaniu kuracjuszom treści ideologicznych związanych z bieżącymi wydarzeniami politycznymi. Należy przy tym podkreślić, że wraz z odwilżą zmienił się również program kulturalno-oświatowy, wyraźnie ograniczono kwestie ideologiczne ${ }^{104}$. Więcej miejsca zaczęto poświęcać elementom typowo rozrywkowym, takim jak dancingi, wieczorki zapoznawcze itp. Koncentrowano się na różnego rodzaju występach, konkursach, turniejach, w których mieli aktywnie uczestniczyć kuracjusze.

103 AAN, ND „PU”, sygn. 4/3, Protokół kontroli działalności DPU Długopole-Zdrój, 22-24 X $1951 \mathrm{r}$.

104 P. Sroka, Turystyka $w$ polskich Sudetach $w$ latach 1945-1956, Wrocław 2013, s. 295-296. 
Prelekcje dotyczące tematyki politycznej i ekonomicznej przestały dominować. Stanowiły zaledwie jeden $\mathrm{z}$ wielu punktów działalności ${ }^{105}$.

W'śód rozrywek, które proponowano kuracjuszom, na szczególną uwagę zasługuja koncerty. Przedstawienia teatralno-operowe były ważnym elementem życia kulturalnego. Od przełomu XVIII i XIX w. w dolnoślaskich uzdrowiskach zaczęły powstawać pierwsze teatry zdrojowe $\mathrm{e}^{106}$. Występy odbywały się także w parkowych pawilonach muzycznych. Zdroje miały własne zespoły - tzw. Badekapellen ${ }^{107}$. Tradycję koncertów kontynuowano po wojnie, co wzbudzało jednak wątpliwości u decydentów: „Gdyby te koncerty wykonywane były przez najwybitniejszych ludzi, to jednak miałyby frekwencję z kuracjuszy-inteligentów. Chłopa słowo »koncert« zawsze odstraszy [...]. Koncert Szopenowski [sic!] był ciężkim dla robotnika, ale pogadanka o Szopenie byłaby mu bardzo miła"108. Ostatecznie z występów nie zrezygnowano. Odbywały się w każdym uzdrowisku, np. w Polanicy-Zdroju - codziennie po południu, w Cieplicach-Zdroju - co dwa dni, a w Kudowie-Zdroju koncertami orkiestry symfonicznej urozmaicano czas dwa razy dziennie ${ }^{109}$. W $1961 \mathrm{r}$. w całym kraju działało 15 orkiestr uzdrowiskowych ${ }^{110}$. W sudeckich kurortach organizowano również trzy cykliczne imprezy związane z muzyką klasyczną: Festiwal Chopinowski w Dusznikach-Zdroju, Festiwal Moniuszkowski w Kudowie-Zdroju oraz Festiwal Wieniawskiego w Szczawnie-Zdroju. Najstarszym był festiwal dusznicki. Jego początki sięgały 1946 r. Koncerty wykonywane w 120 . rocznicę pobytu polskiego kompozytora na kuracji w miejscowym zdroju miały niebagatelne znaczenie propagandowe. Znakomicie wpisywały się w retorykę „powrotu Ziem

105 APKZ, Uzdrowisko Długopole w Długopolu-Zdroju, sygn. 14, Protokół zdawczo-odbiorczy z przekazania majątku PP Uzdrowisko Długopole dla PP Uzdrowisko Lądek, 4 II 1965 r.; APKZ, Uzdrowisko Lądek w Lądku-Zdroju, sygn. 69, Protokół kontroli CZU, 1961 r.; tamże, sygn. 59, Sprawozdanie do protokołu z przekazania przedsiębiorstwa, 14 III $1960 \mathrm{r}$.

${ }^{106}$ G. Balińska, dz. cyt., s. 118.

107 A. Janicki, Muzyka i muzykoterapia w lecznictwie uzdrowiskowym, w: Zdroje Ziemi Kłodzkiej. Historia, przyroda, kultura, przyszłość. Kłodzkie Spotkania Muzealne II, red. W. Ciężkowski, J. Dębicki, R. Gładkiewicz, Wrocław 2006, s. 105-106.

108 APWr, WrWRN, sygn. 1139, Protokół konferencji dyrektorów i lekarzy uzdrowisk dolnoślaskich, Solice-Zdrój, 3-4 X 1948 r.

${ }^{109}$ Cieplickie termy leczq chorych robotników i chłopów, „Służba Zdrowia” 1952, nr 33, s. 4; AAN, ND „PU”, sygn. 4/4, Protokół kontroli w ZPU Kudowa-Zdrój, 16-20 V oraz 23-26 V 1951 r.; tamże, sygn. 4/5, Protokół lustracji doraźnej w ZPU Polanica-Zdrój, 15-17 V $1951 \mathrm{r}$.

${ }^{110}$ A. Zduniak, Muzyka w uzdrowiskach ziemi kłodzkiej, w: Zdroje Ziemi Kłodzkiej..., s. 118. 
Odzyskanych do macierzy". Członkami pierwszego Komitetu Honorowego zostali: minister Ziem Odzyskanych Władysław Gomułka, minister kultury Władysław Kowalski, minister zdrowia Franciszek Litwin oraz wojewoda Stanisław Piaskowski ${ }^{111}$. „Miał to być pierwszy po wojnie festiwal, co miało niemałe znaczenie repolonizacyjne, patriotyczne i integracyjne znaczenie dla naszego społeczeństwa, które nowo przybyłe na ten obszar, nie czuło się jeszcze u siebie" - relacjonował Ignacy Potocki, kierownik Wydziału Inspekcji i Propagandy Zarządu Państwowych Uzdrowisk Dolnoślaskich ${ }^{112}$. Swoje recitale wykonali wówczas uznani pianiści: Zofia Rabcewicz, uczennica Antoniego Rubinsteina, oraz Henryk Sztompka, wyróżniony za najlepsze wykonanie mazurków podczas I Międzynarodowego Konkursu Pianistycznego im. Fryderyka Chopina w 1927 r., uczeń m.in. Ignacego Paderewskiego ${ }^{113}$. W kolejnych latach formuła festiwalu ewoluowała. Od 1954 r. zaczęto zapraszać artystów zagranicznych, a od 1961 r. zdecydowano się na wykonywanie również kompozycji innych autorów ${ }^{114}$. W ramach dusznickiego festiwalu koncerty odbywały się także w sasiednich uzdrowiskach Polanicy-Zdroju, Kudowie-Zdroju, Lądku-Zdroju ${ }^{115}$. Festiwal Moniuszkowski organizowano w Kudowie-Zdroju od 1962 r. ${ }^{116}$ Pierwsza edycja zgromadziła w sumie ok. 20 tys. widzów. Repertuar stanowiły „najpiękniejsze i najbardziej znane arie operowe", a wykonawcami byli artyści Teatru Wielkiego Opery i Baletu w Warszawie oraz Harcerska Orkiestra Symfoniczna Choragwi Warszawskiej ${ }^{117}$. Na przestrzeni kolejnych lat udział w festiwalu brały zespoły operowe, operetkowe oraz orkiestry z całego kraju ${ }^{118}$. Z kolei od 1966 r. w Szczawnie-Zdroju organizowano Międzynarodowy Festiwal im. Henryka Wieniawskiego. Upamiętniał on pobyty kompozytora w tutejszym uzdrowisku w 1885 i $1857 \mathrm{r}$. W koncertach brały udział orkiestry i soliści z różnych części kraju. Występy miały umuzykalniać społeczeństwo oraz przede wszystkim

${ }^{111}$ L. Kaletowa, Festiwale dusznickie w wypowiedziach ich twórców, uczestników $i$ obserwatorów, w: Międzynarodowe Festiwale Chopinowskie w Dusznikach-Zdroju 1946-1999, Wrocław 2000, s. 46, 47.

112 Tamże, s. 46.

113 Zob. http://festival.pl/index.php/pl/archiwum-festiwali?showall=\&start=2 (11 X 2016).

${ }_{114}$ Zob. http://festival.pl/index.php/pl/archiwum-festiwali?showall=\&start=5 (11 X 2016).

${ }_{115}$ Pod znakiem Chopina, „Wiadomości Uzdrowiskowe” 1958, nr 4, s. 91.

116 Festiwal Moniuszkowski w Kudowie, „Służba Zdrowia” 1962, nr 27, s. 4.

117 T.M. Strzelecki, Festiwal Moniuszkowski w Kudowie, „Służba Zdrowia” 1962, nr 32, s. 4.

118 A. Zduniak, dz. cyt., s. 127. 
popularyzować muzykę klasyczną ${ }^{119}$. Trzy festiwale na stałe wpisały się w harmonogram ogólnopolskich imprez kulturalnych. Ich tradycja przetrwała do czasów współczesnych.

Przez cały omawiany okres charakterystyczna była bardzo duża płynność kadr kulturalno-oświatowych. Notorycznie zdarzało się, że referenci nie spełniali stawianych przed nimi wymagań. Uzdrowiska miały duże problemy ze znalezieniem właściwych pracowników, z odpowiednim przygotowaniem ${ }^{120}$. Świetlicowymi lub kaowcami były „osoby niewyrobione politycznie". Wielokrotnie stanowiska referentów nie były obsadzone $^{121}$. Na przykład w Cieplicach-Zdroju: „Prace kulturalno-oświatowe $\mathrm{w}$ uzdrowisku nie były prowadzone należycie. Wydział k[ulturalno]-o[światowy] nie objął swoja akcja swoich wszystkich kuracjuszy. Praca od strony politycznej nie była należycie przemyślana"122. Podobnie było w Polanicy-Zdroju ${ }^{123}$. Próby uświadamiania politycznego i społecznego obywateli podczas kuracji nie przyniosły spodziewanych rezultatów ${ }^{124}$. Wpływ na to miało przede wszystkim skład socjalny kuracjuszy, uzdrowiskowi goście „nie znają form czynnego wypoczynku, nie zasmakowali w kontemplowaniu muzyki czy poezji” 125 .

Kuracjusz musiał podporządkować się tzw. reżimowi sanatoryjnemu, który był swoistą formą kontroli. „Dla tej kuracji wyrzekacie się do pewnego stopnia wolności osobistej, poddając się regulaminowi przepisanemu przez lekarza" - instruowano w poradniku dla skierowanych na leczenie uzdrowiskowe ${ }^{126}$. Trzeba przy tym odnotować, że niektóre dyrekcje w celu zdyscyplinowania pacjentów uciekały się do dość oryginalnych rozwiązań. Tak było w Świeradowie-Zdroju, gdzie przestrzegano: „wydalenie z uzdrowiska podlega ogłoszeniu na tablicy ogłoszeń wszystkich

119 T. Przerwa, Wędrówka po Sudetach. Szkice z historii turystyki ślaskiej przed 1945 r., Wrocław 2005, s. 61; E. Piątek, Z. Piątek, Szczawno-Zdrój. Historia miasta i uzdrowiska, Szczawno-Zdrój 1996, s. 143, 144; A. Zduniak, dz. cyt., s. 118.

${ }^{120} \mathrm{O}$ zagadnieniu zob. też P. Sroka, Wczasy z kaowcem..., s. 33; tenże, Turystyka w polskich Sudetach..., s. 292.

${ }^{121}$ AAN, ND „PU”, sygn. 4/3, Sprawozdanie z podróży służbowej odbytej do Cieplic, Świeradowa, Szczawna, Polanicy, 5-11 VII [1951 r.?]; tamże, Sprawozdanie z lustracji doraźnej w ZPU Długopole-Zdrój, 24 V 1951 r.; tamże, sygn. 4/2, Protokół kontroli w ZPU Szczawno-Zdrój, 10-31 VII 1950 r.

${ }^{122}$ Tamże, sygn. 4/3, Sprawozdanie z podróży służbowej odbytej do Cieplic, Świeradowa, Szczawna, Polanicy, 5-11 VII [1951 r.?]

${ }_{123}$ Tamże, sygn. 4/5, Protokół lustracji doraźnej w ZPU Polanica-Zdrój, 15-17 V $1951 \mathrm{r}$.

${ }_{124}$ P. Sroka, Wczasy z kaowcem..., s. 34.

125 AAN, Zjednoczenie Uzdrowiska Polskie, sygn. 3/20, Kuracjusz w starym stroju.

126 S. Cegliński, M. Kalinowski, dz. cyt., s. 55-56. 
uzdrowisk na terenie Rzeczpospolitej"127. Zapis, pomimo przypuszczalnych pozytywnych skutków wychowawczych, nie spotkał się z aprobata warszawskiej centrali. Surowy regulamin sanatoryjny nie zawsze był przestrzegany. Wątpliwości budził m.in. charakter zabaw urządzanych przez kuracjuszy: „Według zapodań portiera wraz z odchodzącymi gośćmi kawiarni, przenoszącymi się na dalszą zabawę do "Gospody" wychodzi dużo kuracjuszy, którzy wracają po północy lub później. Nikt im właściwie nie zabrania takiego zachowania się"128. Zdarzało się, że kuracjusze wracali do pokojów w środku nocy pijani, urządzali awantury itd. ${ }^{129}$ Problem $\mathrm{z}$ alkoholem był jednym $\mathrm{z}$ wielu, z jakimi musiały zmierzyć się dyrekcje uzdrowisk. Często zdarzały się przypadki zakłócania ciszy nocnej. Naczelna Dyrekcja była zmuszona wydać specjalne Zarzadzenie w sprawie przestrzegania regulaminu w Lecznicach Zdrojowych. Szczególny nacisk kładziono na wspomniany problem pijaństwa. Chorzy mieli bezwzględny zakaz spożywania alkoholu, pod groźbą wyrzucenia $\mathrm{z}$ sanatorium ${ }^{130}$. Również $\mathrm{w}$ materiałach adresowanych do pacjentów przestrzegano: „Używanie alkoholu pod wszelka postacia - w ogóle, a w szczególności w czasie leczenia uzdrowiskowego - niweczy niekiedy w ciagu jednej libacji z takim trudem osiagnięte dobre wyniki lecznicze. Kto namawia sassiadów sanatoryjnych do picia alkoholu i wciaga ich w pijackie towarzystwo, postępuje w sposób niegodny przyzwoitego człowieka. Jeśli zastaniecie w sanatorium takiego "przyjemniaczka», odwróćcie się od niego i dajcie mu odczuć swoja pogardę"131. W świetle wytycznych Naczelnej Dyrekcji kuracjusze nie mogli przebywać poza zakładem po godzinie 23. Zabawy mogły być organizowane do $22^{132}$. Jeszcze bardziej radykalni byli przedstawiciele uzdrowiska w Przerzeczynie-Zdroju, gdzie światła w pokojach miały być gaszone o godzinie 22 . Wszelkie imprezy, które odbywały się na terenie uzdrowiska, musiały się kończyć najpóźniej o 21.30. To samo tyczyło się oglądania telewizji ${ }^{133}$.

Nieodłącznym elementem pobytu w uzdrowisku były również kontakty z personelem - od lekarzy, poprzez kapielowe i pielęgniarki do

${ }^{127}$ AAN, ND „PU”, sygn. 4/7, Sprawozdanie z podróży służbowej do Świeradowa-Zdroju, 3-13 IX 1952 r.

${ }_{128}$ Tamże, sygn. 4/2, Protokół kontroli w ZPU Świeradów-Zdrój, 24-28 VI 1950 r.

129 Tamże, Sprawozdanie z kontroli lotnej w ZPU Świeradów-Zdrój, 29 VIII 1950 r.

130 AAN, ND „PU”, sygn. 1/1, Biuletyn Wewnętrzny nr 2, 10 IV 1949 r., Zarządzenia $\mathrm{nr}$ 403/Leczn./49 w sprawie przestrzegania regulaminu w Lecznicach Zdrojowych.

${ }^{131}$ S. Cegliński, M. Kalinowski, dz. cyt., s. 56-57.

132 AAN, ND „PU”, sygn. 1/1, Biuletyn Wewnętrzny nr 2, 10 IV 1949 r., Zarządzenia nr 403/Leczn./49 w sprawie przestrzegania regulaminu w Lecznicach Zdrojowych.

${ }_{133}$ APKZ, Uzdrowisko Przerzeczyn w Przerzeczynie-Zdroju, sygn. 128, Zarządzenie wewnętrzne nr 10/62, 23 XI 1962 r. 
tzw. bufetowych i portierów. Ciekawym wątkiem, dość często poruszanym w dokumentacji, był zakaz przyjmowania napiwków. W nowej rzeczywistości próbowano skutecznie uporać się z tak wydawałoby się prozaicznym problemem, który był „wynikiem wieloletniej tradycji” 134 . Jednym z rozwiązań miała być zmiana składu socjalnego kuracjuszy: „Dziś, kiedy w uzdrowiskach bawi nowy typ kuracjusza, personel odzwyczai się sam brać napiwki, gdyż nikt ich nie będzie dawał"135. Zarówno dyrekcje poszczególnych uzdrowisk, jak i warszawska centrala „walczyły" z braniem oraz wręczeniem napiwków, m.in. poprzez umieszczanie w pokojach chorych stosownych haseł, które miały wzywać do niedawania ich personelowi ${ }^{136}$. Próbowano również odpowiednio „uświadamiać" pracowników ${ }^{137}$. Nie przynosiło to jednak pożądanego rezultatu, ponieważ „branie napiwków nadal kwitło” 138 .

Pod koniec pobytu należało zapisać się na ostatnią wizytę lekarska. Zalecano, aby przez ostatnie dni przed wyjazdem nie pobierać zabiegów leczniczych, a czas przeznaczyć na przygotowanie się do podróży. „A więc przede wszystkim opuszczajcie sanatorium jako ludzie kulturalni! Oddajcie w bibliotece wypożyczone książki, uregulujcie ewentualne zobowiazania wobec współtowarzyszy. Sprawdźcie [...] dokładny czas odjazdu najodpowiedniejszego pociagu (podróżujcie możliwie w dzień!), zaopatrzcie się w bilety kolejowe. Jeśli potrafiliście oszczędnie gospodarzyć gotówka, możecie zakupić drobne upominki dla najbliższych, będzie to w każdym razie wydatek bardziej celowy aniżeli kupno ćwiartki wódki na oblanie "strzemiennego« z kolegami. Wreszcie wyjeżdżając nie zapomnijcie oddać klucza od pokoju do portierni”"139.

Warto dodać, że dyrekcje poszczególnych uzdrowisk czy też lekarze wydawali dla pacjentów skierowanych na leczenie do uzdrowiska specjalne przewodniki, w których udzielano porad i wskazówek związanych z kuracja ${ }^{140}$. Również $\mathrm{w}$ branżowych publikacjach, takich jak „Służba Zdrowia”, od lat 50. pojawiały się notki, artykuły, które w bardzo sugestywny, propagandowy sposób przedstawiały działalność sudeckich

${ }^{134}$ APWr, WrWRN, sygn. 1139, Protokół konferencji dyrektorów i lekarzy uzdrowisk dolnoślasskich, Solice-Zdrój, 3-4 X 1948 r.

135 Tamże.

136 AAN, ND „PU”, sygn. 4/2, Pismo ND „PU” do ZPU Świeradów-Zdrój, 5 IX 1950 r.

137 APWr, WrWRN, sygn. 1139, Protokół konferencji dyrektorów i lekarzy uzdrowisk dolnośląskich, Solice-Zdrój, 3-4 X 1948 r.

138 AAN, ND „PU”, sygn. 4/3, Sprawozdanie z podróży służbowej odbytej do Cieplic, Świeradowa, Szczawna, Polanicy, 5-11 VII $1951 \mathrm{r}$.

139 S. Cegliński, M. Kalinowski, dz. cyt., s. 58-59.

140 AAN, ND „PU”, sygn. 4/6, Jak zachowywać się żeby odnieść pełną korzyść z kuracji kapielowej, k. 278; S. Cegliński, M. Kalinowski, dz. cyt., s. 5-60. 
uzdrowisk. Jako przykład można przywołać „relacje” robotników i chłopów przebywających w Cieplicach-Zdroju i Lądku-Zdroju: „Wacław Garuń, chłop z kieleckiego [sic!], leczy się tu na koszt Z[wiązku] S[amopomocy] Ch[łopskiej]. Przyjechał przed paru dniami - nie mógł wtedy chodzić, dziś odbywa już przechadzki po pięknych tarasach pawilonowych [...]. Jestem głęboko wdzięczny mej Ludowej Ojczyźnie, że udostępniła mi możliwość leczenia, w tak doskonałych warunkach. Bo powiedzcie sami, czy ja małorolny chłop, mógłbym w Polsce przedwrześniowej myśleć o leczeniu w takim uzdrowisku?” ${ }^{141}$. „Stara chłopka w chusteczce na głowie, również skierowana przez Samopomoc Chłopska, z dumą rozczapierza palce u rąk - mówiąc: »jak to dobrze, że już ruszam rękami. Przyda się na kopanie kartofli«"142. Propagandowy obraz odbiegał od tego, co uzdrowiska oferowały w rzeczywistości. Oczywiście nie można całkowicie kwestionować skuteczności kuracji zdrojowej. Należy pamiętać, że historie przywoływane w czasopismach miały na celu przede wszystkim przyciagnać na kuracje jak największą rzeszę pacjentów oraz przekonać chłopów i robotników, a więc grupy społeczne, które nie korzystały wcześniej z uzdrowisk, do odbycia leczenia. Przywoływane listy i relacje miały niejako oswoić ich $\mathrm{z}$ uzdrowiskami i zapewnić, że ich pobyt w uzdrowisku jest obecnie rzeczą naturalna. Krytyczne uwagi dotyczące działalności zakładów były publikowane jedynie w pokontrolnych protokołach, przeznaczonych wyłącznie do wiadomości dyrekcji poszczególnych uzdrowisk. Tym samym nie docierały do opinii publicznej. W materiałach publicystycznych trafne spostrzeżenia, takie jak to lekarza Adama Kaziora, były rzadkością: „Gdy przegląda się prasę codzienna, nie spotyka się prawie dziennika, aby nie było jakiejśs notatki czy artykułu na temat leczenia zdrojowiskowego [...]. Na podstawie tych tytułów można by sądzić, że rozwój i unowocześnianie uzdrowisk jest nie tylko pierwszoplanowym zadaniem resortu zdrowia, ale po prostu problemem ogólnonarodowym. A tymczasem... Kto pracuje w uzdrowiskach, wie doskonale, że są one pewnego rodzaju piątym kołem u wozu Ministerstwa Zdrowia i C[entralnej] R[ady] Z[wiązków] Z[awodowych]. Ich istnienie - to szereg niekonsekwencji"143.

${ }^{141}$ Cieplickie termy leczq chorych robotników i chłopów..., s. 4.

14270 procent kuracjuszy Ladka - to chtopi i robotnicy, „Służba Zdrowia” 1951, nr 42 , s. 4 .

${ }^{143}$ A. Kazior, dz. cyt., s. 3. 


\section{Podsumowanie}

Wraz z włączeniem lecznictwa uzdrowiskowego do społecznej służby zdrowia opracowano szczegółowy system, przy pomocy którego organizowano cały pobyt kuracjusza w sanatorium. W porównaniu z okresem międzywojennym zmiany były niebagatelne. Kuracja odbywała się w formie turnusu, podczas którego pacjent poddawany był notorycznej kontroli. Odgórnie narzucono sposób spędzania czasu między zabiegami. Obecność w uzdrowisku, oprócz oczywistych korzyści zdrowotnych, miała mieć znaczenie społeczne, propagandowe. Na drodze do realizacji założeń stanął jednak stan permanentnego niedoboru. Brak środków finansowych, niedoinwestowanie uzdrowisk kładły się największym cieniem na życiu codziennym kuracjuszy. Nie było ośrodka, w którym wszystkie elementy składajace się na szeroko pojętą opiekę nad chorymi podczas leczenia funkcjonowałby należycie. Już w momencie przyjazdu do uzdrowiska następowała weryfikacja założeń teoretycznych. Standardem był brud, nieczynne urządzenia lecznicze, zdekompletowane wyposażenie pokoi. Kolejną kwestia, która była szczególnie często komentowana zarówno w pismach-skargach kuracjuszy, jak i protokołach pokontrolnych, było wyżywienie oraz związane z tym problemy z zaopatrzeniem. Uzdrowiska mogły ograniczyć zakupy i serwować kuracjuszom gorsze jakościowo posiłki albo apelować do warszawskiej centrali o zwiększenie limitów na wyżywienie, co ze względu na problemy finansowe, a także z planowościa, nie zawsze było skuteczne ${ }^{144}$. Wpływ na pobyt w sanatorium miał również brak fachowej kadry lekarskiej i personelu pomocniczego. Zjawisko dotyczyło wszystkich ośrodków. Z uwagi na niskie zarobki pracowali tam lekarze tuż po studiach, bez odpowiedniego doświadczenia. Z kolei pracownicy fizyczni przechodzili do innych gałęzi przemysłu. Stałą częścią życia codziennego była praca kulturalno-oświatowa. Elementem, który odróżniał ten typ działalności w uzdrowiskach od miejscowości wczasowych, była tematyka odczytów, wśród której było również miejsce dla kwestii lecznictwa balneologicznego, charakterystyki zabiegów itp. ${ }^{145}$ Oprócz korzyści propagandowych, organizacja rozrywki w uzdrowiskach miała wspomóc leczenie kuracjuszy. Udział w imprezach przeciwdziałał bezczynności, nudzie, aktywizował

${ }^{144}$ APKZ, Uzdrowisko Długopole w Długopolu-Zdroju, sygn. 14, Protokół zdawczo-odbiorczy z przekazania majątku PP Uzdrowisko Długopole dla PP Uzdrowisko Lądek, 4 II 1965 r.

${ }^{145}$ AAN, ND „PU”, sygn. 4/5, Protokół kontroli działalności DPU Przerzeczyn-Zdrój, 4-7 VIII 1951 r.; tamże, sygn. 4/6, Protokół lustracji doraźnej w ZPU Świeradów-Zdrój, 31 V-1 VII 1951 r. 
pacjentó $\mathrm{w}^{146}$. Od połowy lat 50 . nastapiły zmiany w charakterze działalności kulturalno-oświatowej poprzez ograniczenie warstwy ideologicznej ${ }^{147}$.

Po 1945 r. całkowicie przekształcono uzdrowiska, zarówno pod względem systemu leczenia, szeroko pojętej działalności kuracyjnej, jak i organizacji oraz sposobu ich administrowania. Upaństwowione kurorty stały się nieodłączną częścią socjalistycznej, społecznej służby zdrowia oraz centralnie sterowanej, planowej gospodarki, wraz ze wszystkimi tego konsekwencjami. Starano się jak najefektywniej wykorzystać możliwości miejscowych kurortów w zupełnie nowych warunkach społecznych i gospodarczych, co często przynosiło jednak negatywne skutki.

\section{Bibliografia}

\section{Źródła archiwalne}

Archiwum Akt Nowych

Naczelna Dyrekcja „Polskie Uzdrowiska”, sygn. 1/1-1/5, 4/1-4/7, 5/23;

Centralny Zarząd Uzdrowisk, sygn. 2/24, 8/3;

Zjednoczenie Uzdrowiska Polskie, sygn. 3/20;

Ministerstwo Zdrowia, sygn. 49.

Archiwum Państwowe we Wrocławiu, Oddział w Kamieńcu Ząbkowickim

Uzdrowisko Długopole w Długopolu-Zdroju, sygn. 8, 14, 16, 17;

Uzdrowisko Kudowa w Kudowie-Zdroju, sygn. 5/32, 5/33;

Uzdrowisko Lądek-Długopole, sygn. 46, 54, 180;

Uzdrowisko Lądek w Lądku-Zdroju, sygn. 59, 69;

Uzdrowisko Polanica w Polanicy-Zdroju, sygn. 1/318;

Uzdrowisko Przerzeczyn w Przerzeczynie-Zdroju, sygn. 3, 128.

Archiwum Państwowe we Wrocławiu

Wrocławska Wojewódzka Rada Narodowa, sygn. 1139, 1140.

\section{Źródła opublikowane i opracowania}

70 procent kuracjuszy Ladka - to chtopi i robotnicy, „Służba Zdrowia” 1951, nr 42 , s. 4.

Balińska G., Uzdrowiska dolnoślaskie. Problemy rozwoju i ochrony wartości kulturowych do II wojny światowej, Wrocław 1991.

Braki Świeradowa-Zdroju, „Służba Zdrowia” 1952, nr 10, s. 7.

Cegliński S., Kalinowski M., Jak leczyć się w uzdrowisku (Poradnik dla skierowanych na leczenie uzdrowiskowe), Warszawa 1957.

146 S. Cegliński, M. Kalinowski, dz. cyt., s. 28.

${ }^{147}$ P. Sroka, Turystyka w polskich Sudetach..., s. 296. 
Cieplickie termy lecza chorych robotników i chłopów, „Służba Zdrowia” 1952, nr 33, s. 4.

Dobrzyński J., Uzdrowiska państwowe w roku 1951 (szkic sprawozdawczo-statystyczny), „Balneologia Polska” 4, 1953, s. 119-131.

Festiwal Moniuszkowski w Kudowie, „Służba Zdrowia” 1962, nr 27, s. 4.

Grata P., Od Drugiej Rzeczypospolitej do Polski Ludowej. Ewolucja systemu ochrony zdrowia $w$ Polsce $w$ latach 1944-1950, „Polska 1944/45-1989. Studia i Materiały" 15, 2017, s. 5-21.

Jarosz D., „Masy pracujace przede wszystkim”. Organizacja wypoczynku w Polsce 1945-1956, Warszawa-Kielce 2003.

Kaletowa L., Festiwale dusznickie w wypowiedziach ich twórców, uczestników i obserwatorów, w: Międzynarodowe Festiwale Chopinowskie w Dusznikach-Zdroju 1946-1999, Wrocław 2000, s. 46-77.

Kazior A., Zapewnić uzdrowiskom dobrych lekarzy, „Służba Zdrowia” 1962, nr 2, s. 3.

Okuniewski Z., Wczasy lecznicze w Polanicy dla świata pracy, „Służba Zdrowia" 1952, nr 27 , s. 4.

Państwowe Uzdrowiska Dolnoślaskie. Informator na sezon wiosenny 1946, b.m. i d.w.

Piątek E., Piątek Z., Szczawno-Zdrój. Historia miasta i uzdrowiska, Szczawno-Zdrój 1996.

Pod znakiem Chopina, „Wiadomości Uzdrowiskowe” 1958, nr 4, s. 91.

Polanica, „Wiadomości Uzdrowiskowe” 1958, nr 4, s. 92-93.

Przerwa T., Wędrówka po Sudetach. Szkice z historii turystyki ślaskiej przed 1945 r., Wrocław 2005.

Rodan W., List z Długopola, „Służba Zdrowia” 1958, nr 23, s. 6.

Stownik geograficzno-krajoznawczy Polski, red. M.I. Mileska, Warszawa 2000.

Sroka P., Turystyka w polskich Sudetach w latach 1945-1956, Wrocław 2013.

Sroka P., Wczasy z kaowcem, „Pamięć i Przyszłość” 2009, nr 2, s. 29-34.

Strzelecki T.M., Festiwal Moniuszkowski w Kudowie, „Służba Zdrowia” 1962, nr 32, s. 4.

Uzdrowiska dolnoślaskie i ich okolice. Balneologia, historia, przyroda, sztuka, red. A. Falkiewicz, M. Starzewska, Wrocław 1975.

Uzdrowiska w stużbie świata pracy, „Służba Zdrowia” 1952, nr 25, s. 7.

Wolanowski L., Jeden dzień w Polanicy, „Służba Zdrowia” 1950, nr 21, s. 4.

Zielonka-Chełmińska A., Znaczenie akcji kulturalno-oświatowej $w$ uzdrowiskach, „Balneologia Polska” 1, 1951, s. 224-226.

$Z$ obrad Ministerstwa Zdrowia. Lecznictwo uzdrowiskowe w Polsce Ludowej, „Służba Zdrowia” 1949, nr 3, s. 2.

Żelska Z., Jest taki sobie Ladek, „Służba Zdrowia” 1962, nr 34, s. 7. 
Kinga Woźniakowska

Everyday life in the Sudeten sanatoriums in 1950-1966 (Summary)

The article attempts to demonstrate the life in health and rehabilitation resorts in the post-war period and difficulties related to it. The observation of everyday life in sanatoriums in the Sudeten Mountains raised questions about the impact of a centrally managed economy, shortages and changes in the health service on their functioning.

The study spans the period from the year 1950, when the health resort treatment was fully transformed and formalised, to 1966, when the Act on Health Resorts and Health Resort Treatment was passed.

The article is based on archival materials preserved in the Central Archives of Modern Records in Warsaw, the State Archives in Wrocław, and its branch at Kamieniec Zabkowicki. They were supplemented by specialist press. The subject matter brought up in the article has not been addressed in depth so far.

In 1945, due to the shift of the Polish state borders to the west, a large part of Polish health resorts was situated in the Sudeten Mountains. Natural resources exploited in health resorts and their infrastructure had an influence on the development of the whole post-war health resort treatment in Poland. Gradually, both the system of treatment, health resorts activities, and their organisation and management were transformed. Nationalized health resorts became an integral part of the Social Health Service and a centrally managed economy, with all its consequences. A great deal of effort was put to make maximum use of local health resorts in totally new social and economic conditions, often with negative results. A detailed system was worked out to organize the whole stay of the patient in sanatorium. But the system was not implemented due to the state of permanent shortage.

Kinga Woźniakowska - dr nauk humanistycznych (studia w Instytucie Historycznym Uniwersytetu Wrocławskiego). Jej zainteresowania badawcze koncentrują się wokół historii Śląska. Jest autorką publikacji dotyczących uzdrowisk dolnoślaskich oraz ochrony dóbr kultury materialnej wsi. Pracuje w Państwowej Inspekcji Sanitarnej.

Kinga Woźniakowska - PhD in humanities (studies at the Institute of History of the University of Wrocław). Her scholarly interests focus on the history of Silesia region. She is the author of studies on Lower Silesia health resorts and the protection of rural material culture. An employee of the State Sanitary Inspectorate.

E-mail: kinga.janusiak@wp.pl. 